\title{
Temporal and spatial relations between age specific mortality and ambient air quality in the United States: regression results for counties, 1960-97
}

\author{
F W Lipfert, S C Morris
}

See end of article for authors' affiliations

Correspondence to:

Dr F W Lipfert, 23 Carll

Court, Northport, NY

00768, USA;

flipfert@suffolk.lib.ny.us

Accepted

17 October 2001

\begin{abstract}
Objective: To investigate longitudinal and spatial relations between air pollution and age specific mortality for United States counties (except Alaska) from 1960 to the end of 1997

Methods: Cross sectional regressions for five specific periods using published data on mortality, air quality, demography, climate, socioeconomic status, lifestyle, and diet. Outcome measures are statistical relations between air quality and county mortalities by age group for all causes of death, other than AIDS and trauma.

Results: A specific regression model was developed for each period and age group, using variables that were significant $(p<0.05)$, not substantially collinear (variance inflation factor $<2$ ), and had the expected algebraic sign. Models were initially developed without the air pollution variables, which varied in spatial coverage. Residuals were then regressed in turn against current and previous air quality, and dose-response plots were constructed. The validity of this two stage procedure was shown by comparing a subset of results with those obtained with single stage models that included air quality (correlation $=0.88$ ). On the basis of attributable risks computed for overall mean concentrations, the strongest associations were found in the earlier periods, with attributable risks usually less than $5 \%$. Stronger relations were found when mortality and air quality were measured in the same period and when the locations considered were limited to those of previous cohort studies (for $\mathrm{PM}_{2.5}$ and $\mathrm{SO}_{4}{ }^{2}$ ). Thresholds were suggested at $100-130 \mathrm{\mu g} / \mathrm{m}^{3}$ for mean total suspended particulate (TSP), $7-10 \mu \mathrm{gg} / \mathrm{m}^{3}$ for mean sulfate, $10-15 \mathrm{ppm}$ for peak (95th percentile) $\mathrm{CO}, 20-40 \mathrm{ppb}$ for mean $\mathrm{SO}_{2}$. Contrary to expectations, associations were often stronger for the younger age groups $(<65 \mathrm{y})$. Responses to $P M$, $\mathrm{CO}$, and $\mathrm{SO}_{2}$ declined over time; responses in elderly people to peak $\mathrm{O}_{3}$ increased over time as did responses to $\mathrm{NO}_{2}$ for the younger age groups. These results generally agreed with previous prospective cohort and ecological studies for comparable periods, age groups, and pollutants, but they also suggest that the results of those previous studies may no longer be applicable.

Conclusions: Spatially derived relations between air quality and mortality vary significantly by age group and period and may be sensitive to the locations included in the analysis.
\end{abstract}

ong term effects such as developing a new chronic disease imply more serious health consequences than exacerbaLtion of symptoms associated with existing health conditions. Analyses of the costs and benefits of controls on air pollution tend to be dominated by effects on longevity as inferred from long term epidemiological studies. ${ }^{1}$ However, assuming that spatial confounding has been controlled, associations between air quality and annual mortality may have various interpretations: (a) the integral of transient (short term) effects over time within a given period, $(b)$ the creation of new cases of chronic disease, adding to the long term burden of disease, or (c) some combination of acute and chronic responses. Earlier long term prospective cohort studies did not distinguish between these two types of relations, partly because they did not consider the timing between exposure and response. ${ }^{2-4}$ A recent prospective cohort study addressed this question by comparing long term associations between mortality and air quality for periods of exposure before, after, and concurrent with the mortality statistics ${ }^{5}$; most of the significant positive associations were for concurrent exposures, but the pollutant relations differed substantially from those of the earlier cohort studies. As none of these specialised cohorts is representative of the entire population, it is possible that these conflicting results may reflect differences among the cohort subjects, as well as differences in the regression models used. Also, it seems that some of these previous analyses may have been affected by spatial autocorrelation. ${ }^{6}$
The present analysis is intended to explore these issues through the use of county level data for the entire United States, over the full period of ambient air quality monitoring, 1960-1997. Consideration of the entire nation eliminates the problem of specialised cohorts, although as a practical matter, only those locations with air quality data can be considered, which could impose another type of selection bias. The use of such aggregated rather than individual data classifies the study as ecological, although the most important determinant of mortality (age) has been controlled through stratification. However, as personal exposures are not available in sufficient quantity, all air pollution epidemiology studies share this limitation. Thus, the prospective cohort studies are also ecological in this sense, although the term "semi individual" has also been applied to them. ${ }^{7}$ Also, ecological descriptor or "contextual" variables have been used in some prospective cohort studies $^{56}$ as well as terms describing individual characteristics. Such a multilevel approach seems to be gaining acceptance in the epidemiological community. ${ }^{8-10}$ This multilevel approach has been required in part to help control for the

Abbreviations: $P M_{n}$, particulate matter of aerodynamic diameter $<n \mu m$; IPN, Inhalable Particulate Network; AIRS, aerometric information retrieval system; CP, coarse particle; TSP, total suspended particulate; VMTG and VMTD, vehicle miles travelled by gasoline and diesel powered vehicles; VIF, variance inflation factor; MSA, metropolitan area 
Table 1 Statistics of the mortality variables (annual deaths/100000 population)

\begin{tabular}{|c|c|c|c|}
\hline Period & Mean & SD & Counties \\
\hline \multicolumn{4}{|c|}{ Age group 15-44: } \\
\hline 1960-64 & 107 & 32 & 1659 \\
\hline 1970-74 & 88 & 28 & 1624 \\
\hline 1979-81 & 68 & 22 & 1094 \\
\hline 1989-91 & 70 & 26 & 1154 \\
\hline 1995-97 & 74 & 25 & 1253 \\
\hline \multicolumn{4}{|c|}{ Age group 45-64: } \\
\hline 1960-64 & 978 & 210 & 2926 \\
\hline 1970-74 & 989 & 198 & 2927 \\
\hline 1979-81 & 881 & 178 & 2742 \\
\hline 1989-91 & 778 & 177 & 2631 \\
\hline 1995-97 & 701 & 179 & 2645 \\
\hline \multicolumn{4}{|c|}{ Age group 65-74: } \\
\hline 1960-64 & 3370 & 496 & 2943 \\
\hline 1970-74 & 3218 & 484 & 2957 \\
\hline $1979-81$ & 2822 & 411 & 2880 \\
\hline 1989-91 & 2643 & 428 & 2852 \\
\hline 1995-97 & 2577 & 463 & 2832 \\
\hline \multicolumn{4}{|c|}{ Age group 75-84: } \\
\hline 1960-64 & 8048 & 992 & 2956 \\
\hline 1970-74 & 7452 & 902 & 2984 \\
\hline 1979-81 & 6337 & 756 & 2919 \\
\hline 1989-91 & 5943 & 736 & 2957 \\
\hline 1995-97 & 5885 & 841 & 2969 \\
\hline \multicolumn{4}{|c|}{ Age group $\geqslant 85$ : } \\
\hline 1960-64 & 18173 & 3015 & 2749 \\
\hline 1970-74 & 16996 & 2574 & 2879 \\
\hline 1979-81 & 15256 & 2075 & 2794 \\
\hline 1989-91 & 15145 & 1776 & 2883 \\
\hline 1995-97 & 15795 & 2185 & 2945 \\
\hline \multicolumn{4}{|c|}{ Age group 15- $\geqslant 85$ (log-mean mortality):* } \\
\hline $1960-64$ & 7.69 & 0.12 & 1648 \\
\hline 1970-74 & 7.62 & 0.12 & 1622 \\
\hline 1979-81 & 7.47 & 0.12 & 1088 \\
\hline 1989-91 & 7.41 & 0.13 & 1150 \\
\hline 1995-97 & 7.40 & 0.14 & 1252 \\
\hline
\end{tabular}

spatial autocorrelation that was present in the residuals from the models that were based only on individual characteristics. ${ }^{6}$

As discussed in some detail in an earlier paper, ${ }^{11}$ the real concern with ecological studies is not the degree of aggregation (which also exists in time series studies), but with the presence of confounding. All of the classic examples of ecological fallacy ${ }^{12}$ result from failure to adequately control confounding. ${ }^{11}$ Our approach with this analysis has thus been to consider alternative measures of the most important confounders, including smoking habits, socioeconomic factors, and lifestyle variables, in the hopes of capturing the true relations. ${ }^{14}$

The paper begins with a description of data and methods, presents regression results for each of five periods and for each pollutant for which data were available, and then synthesises these findings with a concluding discussion, including suggestions for future cohort studies. The data section emphasises the ambient air quality data and other variables that have been added to our previously developed county level database. ${ }^{15}$ The dependent variables were described in detail in a previous paper. ${ }^{16}$

\section{DATA AND METHODS}

\section{Data}

This analysis uses data from United States counties in the second half of the 20th century, drawn largely from public sources including census, vital statistics, economic, survey, and environmental data. In this context, counties include the District of Columbia and various independent cities—such as Baltimore, St Louis, and many cities in Virginia. Because of the absence of New York City mortality data by borough - that is, county-for the 1960s and 1970s in the mortality database that was available, we created a new "county" to represent the entire city, by population weighting or averaging across the five boroughs, as appropriate.

\section{Dependent variables}

The dependent variables used were described in detail in an earlier report ${ }^{16}$ and comprise mortalities for ages 15-44, 45-64, 65-74, 75-84, and 85 and over, for both sexes and all races combined. All causes of death were considered, except AIDS and trauma. These age groups were selected in an attempt to balance the numbers of deaths included in each. The periods analyzed were 1960-64, 1970-74, 1979-81, 1989-91, and 1995-97 (1997 was the most recent year for which mortality data were available). Rates were computed for counties with 15 or more deaths for the age group and period. A summary measure of mortality across all age groups was computed as the mean of the five logarithms, following the example of Schoen. ${ }^{17}$ Statistics of the mortality variables are given in table 1 .

\section{Independent variables}

The basic set of data on demography, socioeconomics, lifestyles, and environmental factors was described in detail in an earlier report. ${ }^{16}$ Data on smoking, race and ethnicity, education, income, exercise, obesity, and binge drinking are included. Additional data used in this study are described later. Statistics of the independent variables other than air quality are given in table 2 . Note that the peak $\mathrm{CO}$ or $\mathrm{O}_{3}$ concentration for each county is the 95th percentile of daily maximum values, as reported in the AIRS database of the United States Environmental Protection Agency.

\section{Additional demographic data}

The age specific database was used to compute population changes between periods by age group. A summary measure of population change was also computed across the entire period (1960-97). Because population density had been shown to be an important non-linear variable in the previous paper, ${ }^{16}$ its logarithm was added to the dataset, based on 1990 census data.

\section{Climate data}

Elected climate variables were downloaded from a website maintained by Lawrence Berkeley National Laboratory (http:// eande.lbl.gov/IEP/high-radon/files.htrnl). The data are based on 208 geographically distinct weather stations and a 30 year period of record. ${ }^{18}$ Variables were selected for their relevance to outdoor air quality and to indoor exposures. They included: average wind speed, average diurnal swing in barometric pressure and its SD, and infiltration heating and cooling degree-days, all based on either 12 month totals or averages. These variables add wind speed effects to the usual definitions of degree-days; infiltration of outside air is driven by both wind impingement and indoor-outdoor temperature differences. In a comparison of major cities, ordinary degree-days were highly correlated with infiltration degree-days $(R=0.96)$, suggesting that outdoor temperature is the major factor. Infiltration heating and cooling degree-days were strongly negatively correlated $(R=-0.67)$, but a scatter plot showed the relation to be curvilinear. A few anomalous values were found in the infiltration cooling degree-day data for the month of May and locations around Detroit. Accordingly, these values were replaced with estimates predicted by a linear regression on latitude and the April and June cooling degree data. This database did not include climate data for Hawaii, which were imputed from census and National Oceanic and Atmospheric Administration sources. ${ }^{19}$

\section{Diet and additional lifestyle data}

Dietary factors continue to be important in studies of the aetiology of disease and longevity-for example, Leis ${ }^{20}$-but, unfortunately relevant national data are very scarce, especially 
Table 2 Statistics of independent variables (see table 3 for air quality variables)

\begin{tabular}{|c|c|c|c|c|}
\hline $\begin{array}{l}\text { Period or } \\
\text { date of data }\end{array}$ & Description & Mean & SD & Counties \\
\hline 1970 & $\%$ Net migration $(\times 10)$ & -41.65 & 183.82 & 3145 \\
\hline 1970 & $\%$ Black population $(\times 10)$ & 93.58 & 149.59 & 3146 \\
\hline 1970 & $\%$ Other non-white $(\times 10)$ & 12.41 & 65.16 & 3145 \\
\hline 1970 & $\%$ Living in group quarters $(\times 10)$ & 26.7 & 40.04 & 3138 \\
\hline 1970 & $\%$ Hispanic $(\times 10)$ & 28.45 & 103.34 & 3161 \\
\hline 1970 & Median years of school $(\times 10)$ & 108.88 & 14.58 & 3150 \\
\hline 1970 & $\%$ With $\geqslant 4$ y college $(\times 10)$ & 73.44 & 39.61 & 3145 \\
\hline 1970 & $\%$ Unemployment $(\times 10)$ & 45.73 & 24.51 & 3145 \\
\hline 1970 & Median income (US\$) & 7507 & 1912 & 3149 \\
\hline 1970 & $\%$ With residential air conditioning $(\times 10)$ & 309.11 & 201.81 & 3145 \\
\hline 1960-69 & Cigarette sales/capita (by State) & 119.99 & 23.39 & 3143 \\
\hline 1970-79 & Cigarette sales/capita (by State) & 129.57 & 25.36 & 3143 \\
\hline 1980-89 & Cigarette sales/capita (by State) & 123.43 & 19.46 & 3143 \\
\hline 1989-90 & Cigarette sales/capita (by State) & 106.62 & 21.19 & 3143 \\
\hline 1990 & Physicians in office practice//000 population & 7.58 & 6.53 & 3143 \\
\hline 1990 & $\%$ Unemployed & 6.09 & 2.65 & 3143 \\
\hline 1990 & Median income (US\$) & 28483 & 7166 & 3143 \\
\hline 1990 & $\%$ Hispanic & 4.48 & 11.05 & 3143 \\
\hline 1990 & $\%$ Non-white & 10.87 & 17.02 & 3104 \\
\hline 1990 & $\%$ With $\geqslant 4$ college & 13.53 & 6.59 & 3143 \\
\hline 1980 & $\%$ With $\geqslant 4$ y college & 11.49 & 5.47 & 3139 \\
\hline 1950 & Infant mortality & 31.41 & 14.61 & 3107 \\
\hline 1985 & \% Smokers, adults & 26.75 & 2.69 & 3103 \\
\hline 1990 & $\%$ Smokers, adults & 23.96 & 2.29 & 3103 \\
\hline 1985 & $\%$ Obese, adults & 22.4 & 3.59 & 3103 \\
\hline 1990 & $\%$ Obese, adults & 30.02 & 2.53 & 3103 \\
\hline 1985 & $\%$ Without exercise, adults & 34.71 & 9.36 & 3103 \\
\hline 1990 & $\%$ Without exercise, adults & 31.36 & 6.15 & 3103 \\
\hline 1985 & $\%$ Binge drinkers, adults & 5.06 & 2.1 & 3103 \\
\hline 1990 & $\%$ Binge drinkers, adults & 3.44 & 0.99 & 3103 \\
\hline 1990 & $\%$ With hypertension, adults & 23.27 & 2.18 & 3103 \\
\hline 1990 & Average green salads/day (adults) & 0.51 & 0.08 & 3103 \\
\hline 1985 & \% Smokers, elderly & 13.83 & 2.69 & 3103 \\
\hline 1990 & $\%$ Smokers, elderly & 12.02 & 2.11 & 3103 \\
\hline 1985 & $\%$ Obese, elderly & 26.94 & 5.8 & 3103 \\
\hline 1990 & $\%$ Obese, elderly & 37.3 & 3.88 & 3103 \\
\hline 1985 & $\%$ Without exercise, elderly & 45.28 & 8.69 & 3103 \\
\hline 1990 & $\%$ Without exercise, elderly & 43.73 & 7.92 & 3103 \\
\hline 1985 & $\%$ Binge drinkers, elderly & 2.13 & 1.47 & 2922 \\
\hline 1990 & $\%$ Binge drinkers, elderly & 1.49 & 0.89 & 3103 \\
\hline 1990 & $\%$ With hypertension, elderly & 44.7 & 3.6 & 3103 \\
\hline 1990 & Average green salads/day (elderly) & 0.55 & 0.09 & 3103 \\
\hline 1970-74 & Ratio of age $\geqslant 15$ in population, 1970-74/1960-64 & 1.14 & 0.22 & 3058 \\
\hline 1979-81 & Ratio of age $\geqslant 15$ in population, $1979-81 / 1970-74$ & 1.18 & 0.18 & 3058 \\
\hline 1989-91 & Ratio of age $\geqslant 15$ in population, 1989-91/1979-81 & 1.06 & 0.17 & 3063 \\
\hline 1995-97 & Ratio of age $\geqslant 15$ in population, 1995-97/1989-91 & 1.07 & 0.09 & 3115 \\
\hline 1990 & Log (population density) & 3.64 & 1.63 & 3086 \\
\hline 1960 & $\%$ Population change & 7.11 & 38.39 & 3097 \\
\hline 1960 & $\%$ Non-white & 10.82 & 16.63 & 3108 \\
\hline 1960 & Median income (US\$) & 4189 & 1311 & 3096 \\
\hline 1960 & $\%$ Migration & -0.13 & 0.19 & 3109 \\
\hline 1960 & $\%$ Uemployment & 5.19 & 2.52 & 3093 \\
\hline 1960 & $\%$ With satisfactory housing & 57.06 & 17 & 3107 \\
\hline 1960 & $\%$ With air conditioning & 10.11 & 8.86 & 3000 \\
\hline All & Average diurnal swing in barometric pressure & 0.09 & 0.02 & 3118 \\
\hline All & Average wind speed & 4.22 & 0.83 & 3118 \\
\hline
\end{tabular}

when geographic detail is required. Market survey data are presented by Weiss ${ }^{21}$ in the form of ordinal rankings (1-4) of 211 major metropolitan areas. These rankings were assigned to component counties, 844 in all. The variables were consumption of apples, oranges, bacon, beef, cigarettes, snack nuts, red wine; jogging and use of a home gym; and living in a mobile home. We also calculated a summary score from all of these variables that presupposed either beneficial or harmful effects, depending on the variable. However, the usefulness of these data is limited by the relatively crude indices of consumption and by the incomplete coverage of United States counties.

\section{Additional air quality data}

Size classified particulate matter (PM) data have figured prominently in previous studies of long term effects of air pollution ${ }^{4}$ and were also given a high priority in this study. Data from the 1979-84 Inhalable Particulate Network (IPN) were used in recent prospective cohort studies ${ }^{4-6}$; two of these studies ${ }^{56}$ used an expanded version of the IPN data (J Sune, personal communication), which are also used in this study, including $\mathrm{PM}_{2.5}$, coarse particles $\left(\mathrm{PM}_{15}-\mathrm{PM}_{2.5}\right), \mathrm{PM}_{15}$, and the sulfate fraction of $\mathrm{PM}_{2.5}$. Statistics of the air quality variables are listed in table 3.

The United States Environmental Protection Agency recently installed a national network measuring $\mathrm{PM}_{2.5}$ with different methods from those of the IPN. The first year with reasonably complete data is 1999, although sporadic measurements back to the early 1980s are available from aerometric information retrieval system of the EPA (AIRS) using the earlier methods. It was thus important to find whether the 1999 data might also be representative of the 
Table 3 Statistics of the air quality variables (annual means unless otherwise noted)

\begin{tabular}{|c|c|c|c|c|}
\hline Period & Species & Mean & SD & Counties \\
\hline \multicolumn{5}{|c|}{ Particulate matter $\left(\mu \mathrm{g} / \mathrm{m}^{3}\right)$ : } \\
\hline 1960-64 & TSP & 96.92 & 41.81 & 281 \\
\hline 1970-74 & TSP & 69.65 & 28.37 & 1258 \\
\hline $1979-81$ & TSP & 60.51 & 19.63 & 1277 \\
\hline 1989-91 & TSP & 48.78 & 16.28 & 592 \\
\hline 1979-84 & $\mathrm{PM}_{15}$ & 38.30 & 10.73 & 101 \\
\hline 1995-97 & $\mathrm{PM}_{10}$ & 28.64 & 8.05 & 648 \\
\hline 1999 & $\mathrm{PM}_{10}$ & 23.26 & 6.73 & 675 \\
\hline 1979-84 & $\mathrm{PM}_{2.5}$ & 19.19 & 5.66 & 101 \\
\hline 1999 & $\mathrm{PM}_{2.5}$ & 12.97 & 3.74 & 540 \\
\hline \multicolumn{5}{|c|}{ Sulfate aerosol $\left(\mathrm{\mu g} / \mathrm{m}^{3}\right):$} \\
\hline $1960-64$ & $\mathrm{SO}_{4}{ }^{2-\star}$ & 9.92 & 5.36 & 193 \\
\hline 1970-74 & $\mathrm{SO}_{4}^{4-*}$ & 9.31 & 3.77 & 294 \\
\hline $1979-81$ & $\mathrm{SO}_{4}{ }^{2-*}$ & 9.07 & 3.77 & 329 \\
\hline 1982-88 & $\mathrm{SO}_{4}^{2-\star}$ & 7.34 & 3.88 & 216 \\
\hline $1982-88$ & $\mathrm{SO}_{4}{ }^{2-} \dagger$ & 7.55 & 3.39 & 425 \\
\hline 1989-96 & $\mathrm{SO}_{4}^{2-} \dagger$ & 5.85 & 3.18 & 425 \\
\hline 1979-84 & $\mathrm{SO}_{4}{ }^{2-} \ddagger$ & 5.26 & 2.70 & 79 \\
\hline \multicolumn{5}{|c|}{ Sulfur dioxide (ppb): } \\
\hline 1960-69 & $\mathrm{SO}_{2}$ & 56.63 & 48.42 & 42 \\
\hline 1970-74 & $\mathrm{SO}_{2}$ & 16.18 & 14.62 & 279 \\
\hline 1979-81 & $\mathrm{SO}_{2}$ & 9.04 & 5.65 & 480 \\
\hline 1989-91 & $\mathrm{SO}_{2}$ & 7.20 & 4.13 & 411 \\
\hline 1995-97 & $\mathrm{SO}_{2}$ & 4.94 & 2.69 & 393 \\
\hline \multicolumn{5}{|c|}{ 95th percentile CO (ppm): } \\
\hline 1960-69 & $\mathrm{CO}$ & 13.81 & 8.47 & 44 \\
\hline 1970-74 & $\mathrm{CO}$ & 9.64 & 5.63 & 206 \\
\hline 1979-81 & $\mathrm{CO}$ & 5.90 & 3.54 & 272 \\
\hline 1989-91 & $\mathrm{CO}$ & 2.69 & 1.22 & 246 \\
\hline 1995-97 & $\mathrm{CO}$ & 1.72 & 0.76 & 261 \\
\hline \multicolumn{5}{|c|}{ Nitrogen dioxide (ppb): } \\
\hline 1960-69 & $\mathrm{NO}_{2}$ & 35.76 & 11.22 & 33 \\
\hline 1970-74 & $\mathrm{NO}_{2}$ & 28.11 & 12.62 & 151 \\
\hline 1979-81 & $\mathrm{NO}_{2}$ & 20.06 & 10.22 & 236 \\
\hline 1989-91 & $\mathrm{NO}_{2}$ & 18.02 & 8.43 & 194 \\
\hline 1995-97 & $\mathrm{NO}_{2}$ & 15.43 & 7.35 & 240 \\
\hline \multicolumn{5}{|c|}{ 95th percentile $\mathrm{O}_{3}(\mathrm{ppb})$ : } \\
\hline 1970-74 & $\mathrm{O}_{3}$ & 146.99 & 51.63 & 156 \\
\hline 1979-81 & $\mathrm{O}_{3}$ & 120.12 & 36.30 & 452 \\
\hline 1989-91 & $\mathrm{O}_{3}$ & 84.71 & 14.77 & 439 \\
\hline 1995-97 & $\mathrm{O}_{3}$ & 73.18 & 10.01 & 520 \\
\hline \multicolumn{5}{|c|}{ Vehicle-miles travelled/sq mile: } \\
\hline $1985-97$ & VMTG & 1.84 & 9.20 & 3084 \\
\hline $1985-97$ & VMTG & 20.21 & 37.70 & $99 \S$ \\
\hline 1985-97 & VMTD & 0.12 & 43.00 & 3084 \\
\hline 1985-97 & VMTD & 0.98 & 1.75 & $99 \S$ \\
\hline
\end{tabular}

*Glass-fibre filters; †estimated values; †teflon filters; §counties with IPN PM ${ }_{2.5}$ data.

VMTG and VMTD, vehicle miles travelled by gasoline and diesel powered vehicles.

spatial distribution of earlier years, specifically for the 1995-7 period for which the latest mortality data were available. This back extrapolation was complicated by the change that the EPA made in reporting particulate air quality data. Before 1998, concentrations were adjusted to standard temperature and pressure, but recent data are mainly reported for the atmospheric conditions under which the measurements were made, although some stations reported the data both ways. We downloaded $\mathrm{PM}_{10}$ and $\mathrm{PM}_{2.5}$ data from the AIRS website from the 1980s to 1999 and found very slightly lower concentrations for the unadjusted data and that the minimum national average of county averages occurred in 1997. As these trends and adjustment differences are not significant, we chose the adjusted reporting basis for consistency with previous data and used unadjusted values for 47 counties to augment the adjusted data, resulting in 787 counties with $\mathrm{PM}_{10}$ data. These values were judged to be reasonable estimates for the period 1995-7.

Similar questions arose for the $\mathrm{PM}_{2.5}$ data, which were mainly reported without adjustment to standard conditions in 1999. Only 17 counties had data from both methods for 1999 , and one of these was a New York City traffic site that showed substantially higher concentrations. Although comparison between methods showed more scatter than expected (the SE of estimate was $3.3 \mu \mathrm{g} / \mathrm{m}^{3}$ ), the slope was $0.98 \pm 0.21$ and the correlation was 0.78 , suggesting that the two methods could be interchanged. We then compared temporal trends by comparing $\mathrm{PM}_{2.5}$ concentrations in counties that had data for 1999 , 1992-97, and 1982-91. With the 1999 data as the independent variable, the slopes for these two older periods were not significantly different from unity, with SEs of the estimate from $3-4 \mu \mathrm{g} / \mathrm{m}^{3}$ and correlations of 0.87 and 0.76 . These measures of error are comparable with those reported by Abbey et $a l^{22}$ in estimating $\mathrm{PM}_{2.5}$ from airport visibility. We thus concluded that the spatial variability in $\mathrm{PM}_{2.5}$ among counties far exceeds the year to year variability and thus that the 1999 data seem to be appropriate to represent the spatial gradients in $\mathrm{PM}_{2.5}$ exposures in $1995-97$ as well as in 1989-91.

Because there were only 538 counties with $1999 \mathrm{PM}_{2.5}$ data, not all of which corresponded to counties with $\mathrm{PM}_{10}$ data, when we subtracted $\mathrm{PM}_{25}$ from $\mathrm{PM}_{10}$ to estimate coarse particle (CP) concentrations, only 408 counties were represented.

Problems were also found with data on ambient sulfate $\left(\mathrm{SO}_{4}^{2-}\right)$ aerosol, which has also been important in previous long term mortality studies. Here, the problems of measurement accuracy relate to the use of reactive glass fibre filters on the high volume total suspended particulate (TSP) samplers from which the bulk of the $\mathrm{SO}_{4}^{2-}$ data have been derived. These filters create $\mathrm{SO}_{4}^{2-}$ artifact by oxidising the $\mathrm{SO}_{2}$ in the ambient air that is drawn through the filter. However, the 1979-84 IPN samplers used less reactive filters and thus produced lower $\mathrm{SO}_{4}^{2-}$ concentrations. A regression based on 64 counties with both types of $\mathrm{SO}_{4}^{2-}$ data produced a slope of $1.02 \pm 0.15$ with an intercept of $4.87 \mu \mathrm{g} / \mathrm{m}^{3}\left(R=0.74\right.$, with an SE of $\left.2.4 \mu \mathrm{g} / \mathrm{m}^{3}\right)$, which is very similar to previous estimates. ${ }^{23}$ As the filter artifact is produced by ambient $\mathrm{SO}_{2}$, an alternative model was investigated with ambient $\mathrm{SO}_{2}$ as an additional predictor; it was not significant. We thus concluded that $\mathrm{SO}_{4}^{2-}$ as measured on TSP filters would be the standard measure of $\mathrm{SO}_{4}^{2-}$ in this study, for all periods, but that $4.9 \mu \mathrm{g} / \mathrm{m}^{3}$ should be subtracted from the overall mean value when estimating attributable risks of mortality to preclude attributing risk to $\mathrm{SO}_{4}{ }^{2-}$ concentrations that did not actually exist in ambient air.

The remainder of the data on ambient air quality, for $\mathrm{CO}$, $\mathrm{NO}_{2}, \mathrm{O}_{3}, \mathrm{SO}_{2}, \mathrm{TSP}$, and $\mathrm{PM}_{10}$ were downloaded from AIRS for years after 1982 and retrieved from our 1960-81 database that had been assembled previously from AIRS sources. ${ }^{16} \mathrm{No}_{3}$ data were available before 1970 , and no annual $\mathrm{O}_{3}$ averages are available from the AIRS reporting system for any period (AIRS annual averages for $\mathrm{O}_{3}$ refer to the annual average of the daily maxima). The periods of data were initially matched to the mortality periods already listed. However, there were too few observations in the 1960-4 period for a useful analysis; thus, this period was extended to 1969 to augment the air quality data set. This period precedes the establishment of controls for air pollution and thus shows little in the way of temporal trends.

The general protocol for processing data on air quality was as follows: data were retrieved from AIRS for individual years and measurement sites. For PM, which was mainly sampled every 6th day, a site-year was retained if it had 25 or more 24 hour samples. For data collected hourly, the site retention criterion was set at 4500 hours. The numbers of sites in each county varied from 1 to 69 , depending upon the pollutant. For the analyses reported later, we used arithmetic means and 95th percentiles, averaged spatially over each county. The 95th percentiles serves as a robust measure of peak concentration during the period.

As well as these measured data on ambient air quality, we also obtained a file of estimated county level traffic, as annual vehicle-miles traveled by gasoline powered and diesel powered vehicles (VMTG and VMTD). Data were supplied by the EPA 
Table 4 Attributable risks of mortality (1960-4) from different air quality variables

\begin{tabular}{|c|c|c|c|c|}
\hline & \multicolumn{2}{|c|}{$\begin{array}{l}\text { TSP, 1960-4 All } \\
\text { locations }\end{array}$} & \multicolumn{2}{|c|}{$\begin{array}{l}\text { Peak } 0_{3}, 1970-4 \text { All } \\
\text { locations }\end{array}$} \\
\hline & Risk & SE & Risk & SE \\
\hline Ages 15-44 & $0.0967 *$ & 0.0226 & -0.0201 & 0.0370 \\
\hline Ages 45-64 & $0.0479 *$ & 0.0188 & -0.0171 & 0.0273 \\
\hline Ages $65-74$ & 0.0499 * & 0.0163 & 0.0526 * & 0.0261 \\
\hline Ages 75-84 & $0.0414^{*}$ & 0.0116 & $0.0488^{*}$ & 0.0208 \\
\hline Ages $\geqslant 85$ & 0.0141 & 0.0142 & 0.0157 & 0.0200 \\
\hline \multirow[t]{2}{*}{ Log mean } & $0.0415^{*}$ & 0.0111 & 0.0132 & 0.0176 \\
\hline & \multicolumn{2}{|c|}{$\begin{array}{l}\mathrm{SO}_{4}^{2-}, 1960-4 \text { All } \\
\text { locations }\end{array}$} & \multicolumn{2}{|c|}{$\begin{array}{l}\mathrm{NO}_{2}, 1960-9 \text { All } \\
\text { locations }\end{array}$} \\
\hline Ages 15-44 & 0.0431 * & 0.0101 & $0.1950 *$ & 0.0835 \\
\hline Ages 45-64 & $0.0223^{*}$ & 0.0081 & -0.0158 & 0.0693 \\
\hline Ages 65-74 & $0.0317^{*}$ & 0.0070 & 0.0053 & 0.0508 \\
\hline Ages 75-84 & $0.0257^{*}$ & 0.0050 & 0.0656 & 0.0444 \\
\hline Ages $\geqslant 85$ & $0.0135^{*}$ & 0.0059 & 0.0575 & 0.0491 \\
\hline \multirow[t]{2}{*}{ Log mean } & $0.0168^{*}$ & 0.0045 & 0.0428 & 0.0393 \\
\hline & \multicolumn{2}{|c|}{$\begin{array}{l}\mathrm{SO}_{2}, 1960-9 \text { All } \\
\text { locations }\end{array}$} & \multicolumn{2}{|c|}{$\begin{array}{l}\text { Peak CO, 1960-9 All } \\
\text { locations }\end{array}$} \\
\hline Ages 15-44 & $0.1322 *$ & 0.0308 & 0.1299 * & 0.0341 \\
\hline Ages 45-64 & $0.0577^{*}$ & 0.0280 & 0.0340 & 0.0280 \\
\hline Ages $65-74$ & 0.0501 * & 0.0252 & -0.0058 & 0.0220 \\
\hline Ages 75-84 & $0.0569^{*}$ & 0.0163 & 0.0121 & 0.0188 \\
\hline Ages $\geqslant 85$ & 0.0087 & 0.0227 & 0.0374 & 0.0225 \\
\hline Log mean & $0.0422^{*}$ & 0.0153 & $0.0365^{*}$ & 0.0149 \\
\hline
\end{tabular}

(G Stella, personal communication) for 1985, 1990, and 1997, but we found the three years to be highly collinear and thus considered only one of them. To normalise for county size, we divided VMT by the county land area. Note that (vehiclexmiles/year)/miles ${ }^{2}$ would have the form of an emission density (g/year/miles ${ }^{2}$ ) when multiplied by a vehicle emission factor in the usual units of $\mathrm{g} /$ miles. These values tend to be log normally distributed, with many very low values in the rural counties. However, urban counties will tend to dominate the regressions (the VMT data in table 1 for $n=99$ represent data for counties in the IPN network having data on $\left.\mathrm{PM}_{2.5}\right)$. We found nearly unity correlations between VMTG and VMTD, even after normalising by land area and restricting the data set to larger counties in various ways; thus, it was only necessary to evaluate responses to one of the measures (VMTG).

\section{Methods}

\section{Timing of risk factors}

An important issue that has largely been neglected in cross sectional studies of long term effects of air pollution is that of latency effects of exposures to air pollution and of other (competing) risks. For example, it is well known that the effects of smoking on lung cancer have a latency of about 20 years $^{24}$; it seems reasonable to expect the latency of effects of air pollution to be similar. Rose ${ }^{25}$ concluded that the delay between exposure to major coronary risk factors and maximum effects on mortality from coronary heart disease was 10 years or more, based on correlations with antecedent data on blood pressure and cholesterol. With respect to effects on epidemiology, Rothman ${ }^{26}$ concluded that mis-specifying the induction or latency period of a specific type of exposure constitutes non-differential misclassification and thus will tend to bias effect estimates toward the null. However, it follows that in multivariate analyses, differences in misspecifying induction periods among competing risk factors could also result in spurious transfer of causality. ${ }^{27}$

The persistence of socioeconomic risk factors over a lifetime has been studied more recently, especially for cardiovascular disease. The "fetal origins" hypothesis has been argued effectively by Barker ${ }^{28}$ and supported by epidemiology studies in several countries. Shaheen ${ }^{29}$ found "convincing evidence" that the foundations of chronic airflow obstruction begin in utero and early childhood; low birthweight and undernutrition were found to be important risk factors for adult death from chronic obstructive pulmonary disease, for example. We used the 1950 infant mortality for each county (the earliest year with data available in electronic format) as an index of earlier adverse socioeconomic conditions, in keeping with this hypothesis.

Blakely and Woodward ${ }^{8}$ concluded that "investigation of lag times ... is required." Our approach to the risk factor timing problem is strictly empirical. We determined which properties of counties seemed to be stable over time, based on correlations between periods. For those that vary considerably over the total period (1960-97), we explored alternative regression models to determine the latency periods that seem to have the most predictive power. For ambient air quality, we followed the general protocol used in a previous prospective study of United States veterans. ${ }^{5}$ We consider that a significant association with air quality measured before the period of mortality may be considered indicative of chronic or long term delayed responses, those measured concurrently with the mortality period may also reflect the time integral of acute responses, and significant associations between mortality and subsequent exposure can only reflect indirect relations- such as those arising from collinearity between periods.

\section{Regression analysis protocols}

A critical problem with long term studies of the effects of air pollution is that the numbers of counties with valid air quality data vary substantially (from about 40 to over 1200) by pollutant and over time. We used a staged regression approach to deal with this problem. The first stage was the development of a robust national model for each dependent variable, excluding the air quality variables to maximise the numbers of observations that may be used (from about 800 to 3000). We then used regressions with the residuals from these models to identify the pollutants of primary interest, as the second stage. Scatter plots of residuals versus pollutants may be used to evaluate the shapes of the implied dose-response functions, and spatial distributions of the residuals (for example, by state or region) may be used to assess the presence of spatial autocorrelation. The final step would then be to re-evaluate the basic models with those pollutants included, ultimately in combination.

The regression analysis for each period began with a stepwise search for a specification (model) for each mortality variable, selecting the independent variables that met the following criteria: significant $(\mathrm{p}<0.05)$, an acceptable degree of multicollinearity (as assessed by a variance inflation factor $(\mathrm{VIF})<2$ ), and the expected algebraic sign of the effect on mortality (positive for smoking, lack of exercise, hypertension, population density, obesity, unemployment, percentage of black population, and 1950 infant mortality; negative for increased income or education, favourable climate, percentage of Hispanic population, and population increase). We noted that the alcohol consumption variable could have either sign, depending on the age group. We used the number of physicians per capita as an index of access to medical care; this variable tended to be positive for the younger age groups and negative for elderly people. We interpreted the positive signs as an indication that more physicians may be found where the need is greatest (as opposed to the physicians causing mortality) and thus deleted the physician supply variable from those models (primarily the younger age groups). ${ }^{30}$ Residential air conditioning tended to have a positive effect on mortality and, as expected, was highly collinear with cooling degree-days. We retained the air conditioning variable, 
Table 5 Attributable risks of mortality (1970-4) from different air quality variables

\begin{tabular}{|c|c|c|c|c|c|c|}
\hline & \multicolumn{2}{|c|}{$\begin{array}{l}\text { TSP, 1970-74 } \\
\text { All locations }\end{array}$} & \multicolumn{2}{|c|}{$\begin{array}{l}\text { TSP, 1960-64 } \\
\text { All locations }\end{array}$} & \multicolumn{2}{|c|}{$\begin{array}{l}\text { TSP, 1970-74 } \\
\text { TSP, 1960-64 }\end{array}$} \\
\hline & Risk & SE & Risk & SE & Risk & SE \\
\hline Ages $15-44$ & 0.0134 & 0.0151 & $0.0584^{*}$ & 0.0265 & 0.0155 & 0.0326 \\
\hline Ages $45-64$ & -0.0042 & 0.0094 & $0.0342 *$ & 0.0173 & 0.0199 & 0.0211 \\
\hline Ages $65-74$ & 0.0116 & 0.0079 & 0.0273 & 0.0148 & 0.0151 & 0.0158 \\
\hline Ages $75-84$ & $0.0165^{*}$ & 0.0062 & $0.0444^{*}$ & 0.0105 & $0.0450^{*}$ & 0.0129 \\
\hline Ages $\geqslant 85$ & 0.0134 & 0.0076 & $0.0479 *$ & 0.0114 & $0.0415^{*}$ & 0.0141 \\
\hline \multirow[t]{2}{*}{ Log mean } & 0.0084 & 0.0056 & $0.0377^{*}$ & 0.0106 & 0.0209 & 0.0132 \\
\hline & \multicolumn{2}{|c|}{$\begin{array}{l}\mathrm{SO}_{4}{ }^{2-}, 1970-74 \\
\mathrm{All}^{2} \\
\text { locations }\end{array}$} & \multicolumn{2}{|c|}{$\begin{array}{l}\mathrm{SO}_{4}{ }^{2-}, 1960-64 \\
\mathrm{All}^{2} \text { locations }\end{array}$} & \multicolumn{2}{|c|}{$\begin{array}{l}\mathrm{SO}_{4}{ }^{2-}, \\
\mathrm{SO}_{4}{ }^{2-}, 1970-74 \\
1960-64\end{array}$} \\
\hline Ages $15-44$ & 0.0162 & 0.0155 & 0.0424 * & 0.0135 & 0.0323 & 0.0186 \\
\hline Ages $45-64$ & 0.0140 & 0.0091 & 0.0154 & 0.0085 & 0.0241 * & 0.0109 \\
\hline Ages $65-74$ & $0.0165^{*}$ & 0.0078 & 0.0076 & 0.0069 & 0.0191 * & 0.0088 \\
\hline Ages $75-84$ & $0.0166^{*}$ & 0.0057 & $0.0138^{*}$ & 0.0048 & $0.0234^{*}$ & 0.0061 \\
\hline Ages $\geqslant 85$ & $0.0133^{*}$ & 0.0064 & $0.0152 *$ & 0.0049 & $0.0146 *$ & 0.0065 \\
\hline \multirow[t]{2}{*}{ Log mean } & 0.0075 & 0.0058 & $0.0113^{*}$ & 0.0049 & $0.0146 *$ & 0.0062 \\
\hline & \multicolumn{2}{|c|}{$\begin{array}{l}\mathrm{SO}_{2,1970-74} \\
\mathrm{All}^{\prime} \quad \text { locations }\end{array}$} & \multicolumn{2}{|c|}{$\begin{array}{l}\mathrm{SO}_{2,}, 1960-69 \\
\text { All }^{2} \quad \text { locations }\end{array}$} & \multicolumn{2}{|c|}{$\begin{array}{l}\mathrm{SO}_{2}, 1970-74 \\
\mathrm{SO}_{2}, 1960-69\end{array}$} \\
\hline Ages $15-44$ & $0.0439 *$ & 0.0127 & $0.2434^{*}$ & 0.0494 & $0.0998^{*}$ & 0.0434 \\
\hline Ages $45-64$ & $0.0177^{*}$ & 0.0086 & 0.0353 & 0.0353 & 0.0153 & 0.0239 \\
\hline Ages $65-74$ & $0.0151^{*}$ & 0.0077 & 0.0147 & 0.0250 & 0.0147 & 0.0165 \\
\hline Ages $75-84$ & 0.0097 & 0.0057 & 0.0401 * & 0.0146 & $0.0238^{*}$ & 0.0101 \\
\hline Ages $\geqslant 85$ & 0.0049 & 0.0066 & 0.0265 & 0.0175 & 0.0147 & 0.0119 \\
\hline \multirow[t]{3}{*}{ Log mean } & $0.0159 *$ & 0.0053 & $0.0477^{*}$ & 0.0197 & $0.0274 *$ & 0.0135 \\
\hline & \multirow{2}{*}{\multicolumn{2}{|c|}{$\begin{array}{l}\mathrm{NO}_{2}, 1970-74 \\
\text { All } \quad \text { locations }\end{array}$}} & \multirow{2}{*}{\multicolumn{2}{|c|}{$\begin{array}{l}\text { PeakO }_{3}, 1970-74 \\
\text { All locations }\end{array}$}} & \multirow{2}{*}{\multicolumn{2}{|c|}{$\begin{array}{l}\text { Peak CO, 1970-74 } \\
\text { All locations }\end{array}$}} \\
\hline & & & & & & \\
\hline Ages 15-44 & $0.0904^{*}$ & 0.0270 & -0.0385 & 0.0402 & $0.0553^{*}$ & 0.0240 \\
\hline Ages $45-64$ & -0.0210 & 0.0190 & -0.0313 & 0.0252 & 0.0181 & 0.0148 \\
\hline Ages $65-74$ & -0.0296 & 0.0158 & 0.0279 & 0.0219 & -0.0146 & 0.0134 \\
\hline Ages $75-84$ & $-0.0258^{*}$ & 0.0110 & $0.0470 *$ & 0.0169 & -0.0128 & 0.0098 \\
\hline Ages $\geqslant 85$ & -0.0121 & 0.0111 & 0.0153 & 0.0165 & -0.0151 & 0.0093 \\
\hline Log-mean & -0.0008 & 0.0104 & 0.0040 & 0.0139 & 0.0038 & 0.0086 \\
\hline
\end{tabular}

interpreting it as an ecological marker for hot weather (as opposed to a protective device for individual people); this variable could also serve as a possible indication of increased concentrations of indoor air pollutants. As the dietary and other lifestyle variables were only available for a subset of counties and only for the later periods, we have not introduced them into the models at this point in the project.

Having defined an acceptable model for each mortality variable for each period, based on the common dataset for the dependent variables and unlimited by constraints on air quality data, we then ran an individual regression with predefined variables for each, generally involving more counties, and computed the residuals. The distributions of residuals were generally normal, especially for the derived mortality variables. We also computed mean residuals for six geographically defined regional subsets, to examine the extent and directions of regionality. The air quality analyses reported here were based on the relations between these residuals, obtained from the master national sets, and the various measures of air quality, for which the numbers of counties varied by more than an order of magnitude.

It is of course possible that some air quality measures may show a degree of collinearity with other independent variables-such as population density and climate variables. When the air quality measure was added to the model, these relations competed and could affect the implied relation with mortality. To answer this question, we calculated the mortality-pollution relations both ways for 56 regressions with data from 1960-64, a period for which relations tended to be strong. The correlation between the two sets of regression coefficients was 0.88 , with a slope of 0.904 and an SE of 0.066 (not significantly different from unity). For the regression
SEs, there was a small significant difference, with the full model values about $9 \%$ higher, on average, but the correlation between the two sets of errors was 0.99. Thus, our use of the two stage procedure slightly overstates significance but does not bias the estimated risks. We thus concluded that the residual based coefficient estimates would be acceptable for this first round analysis.

The residuals were also used to estimate dose-response relations, as follows. We listed them along with the pollutant values, in increasing order of pollution. We then computed and plotted running averages, with spans of the order of not more than $10 \%-20 \%$ of the data set. Too large a span obscures the extreme values that may be critical in identifying possible thresholds. In some cases, we used alternative span lengths to check for consistent results.

\section{Estimates of attributable risks}

Because of the need to compare risks of mortality by pollutant, a metric is needed that is independent of the units of measurement—such as the incremental mortality risk associated with the presence of that pollutant. We have based these attributable risks on the mean concentrations of pollutant for the largest datasets for each pollutant and period. Although arguments could be made for using the median concentrations instead (which may be more likely to correspond to actual exposures for episodic pollutants) or for subtracting background concentrations, this choice is simpler and consistent with previous studies. ${ }^{51-33}$

\section{RESULTS}

\section{Air quality correlations}

This analysis attempts to make distinctions among many air quality variables that differ according to species, timing, and, 
Table 6 Attributable risks of mortality (1979-81) from different air quality variables

\begin{tabular}{|c|c|c|c|c|c|c|c|c|c|c|c|c|c|c|}
\hline & \multicolumn{2}{|c|}{$\begin{array}{l}\text { TSP, 1979-81 } \\
\text { All locations }\end{array}$} & \multicolumn{2}{|c|}{$\begin{array}{l}\text { TSP, 1970-74 } \\
\text { All locations }\end{array}$} & \multicolumn{2}{|c|}{$\begin{array}{l}\text { TSP, 1960-64 } \\
\text { All locations }\end{array}$} & \multicolumn{2}{|c|}{$\begin{array}{l}\text { TSP, 1979-81 } \\
\text { TSP, 1970-74 }\end{array}$} & \multicolumn{2}{|c|}{$\begin{array}{l}\text { TSP, 1979-81 } \\
\text { TSP, 1960-64 }\end{array}$} & \multicolumn{2}{|c|}{$\begin{array}{l}\text { TSP, 1970-74 } \\
\text { TSP, } 1960-64\end{array}$} & & \\
\hline & Risk & SE & Risk & SE & Risk & SE & Risk & SE & Risk & SE & Risk & SE & & \\
\hline Ages $15-44$ & 0.0009 & 0.0214 & 0.0159 & 0.0150 & 0.0323 & 0.0215 & 0.0124 & 0.0232 & 0.0066 & 0.0330 & 0.0291 & 0.0257 & & \\
\hline Ages 45-64 & 0.0097 & 0.0142 & 0.0092 & 0.0101 & $0.0574^{*}$ & 0.0175 & 0.0015 & 0.0158 & 0.0015 & 0.0276 & 0.0342 & 0.0214 & & \\
\hline Ages $65-74$ & 0.0114 & 0.0117 & $0.0240 *$ & 0.0081 & $0.0289 *$ & 0.0142 & 0.0018 & 0.0129 & -0.0084 & 0.0214 & 0.0070 & 0.0170 & & \\
\hline Ages $75-84$ & 0.0072 & 0.0108 & 0.0114 & 0.0074 & $0.0290 *$ & 0.0119 & 0.0054 & 0.0119 & -0.0062 & 0.0180 & 0.0189 & 0.0142 & & \\
\hline Ages $\geqslant 85$ & 0.0138 & 0.0106 & $0.0200 *$ & 0.0077 & $0.0368^{*}$ & 0.0108 & 0.0178 & 0.0119 & 0.0292 & 0.0167 & $0.0347^{*}$ & 0.0131 & & \\
\hline \multirow[t]{3}{*}{ Log mean } & 0.0036 & 0.0085 & 0.0155 & 0.0061 & $0.0242^{*}$ & 0.0100 & 0.0030 & 0.0097 & & & 0.0104 & 0.0125 & & \\
\hline & \multicolumn{6}{|c|}{ Inhalable particulate network data } & & & & & & & & \\
\hline & \multicolumn{2}{|c|}{$\begin{array}{l}\mathrm{PM}_{2.5}, 1979-84 \\
\text { All locations }\end{array}$} & \multicolumn{2}{|c|}{$\begin{array}{l}\mathrm{PM}_{15}, 1979-84 \\
\text { All locations }\end{array}$} & \multicolumn{2}{|c|}{$\begin{array}{l}\text { Fine } \mathrm{SO}_{4}^{2-}, 1979-84 \\
\text { All locations }\end{array}$} & & & & & & & & \\
\hline Ages $15-44$ & 0.0897 & 0.0568 & 0.0356 & 0.0615 & $0.0940 *$ & 0.0397 & & & & & & & & \\
\hline Ages $45-64$ & $0.1013^{*}$ & 0.0459 & 0.0491 & 0.0500 & $0.1117^{*}$ & 0.0253 & & & & & & & & \\
\hline Ages $65-74$ & $0.0618^{*}$ & 0.0297 & 0.0214 & 0.0324 & $0.0707^{*}$ & 0.0184 & & & & & & & & \\
\hline Ages $75-84$ & 0.0791 * & 0.0235 & 0.0512 & 0.0260 & $0.0759^{*}$ & 0.0131 & & & & & & & & \\
\hline Ages $\geqslant 85$ & $0.0649 *$ & 0.0228 & $0.0555^{*}$ & 0.0247 & $0.0492^{*}$ & 0.0129 & & & & & & & & \\
\hline \multirow[t]{2}{*}{ Log mean } & $0.0515^{*}$ & 0.0210 & 0.0203 & 0.0241 & $0.0580^{*}$ & 0.0114 & & & & & & & & \\
\hline & \multicolumn{2}{|c|}{$\begin{array}{l}\mathrm{SO}_{4}^{2-}, 1979-81 \\
\text { All locations }\end{array}$} & \multicolumn{2}{|c|}{$\begin{array}{l}\mathrm{SO}_{4}^{2-}, 1970-74 \\
\text { All locations }\end{array}$} & \multicolumn{2}{|c|}{$\begin{array}{l}\mathrm{SO}_{4}{ }^{2-}, 1960-64 \\
\text { All locations }\end{array}$} & \multicolumn{2}{|c|}{$\begin{array}{l}\mathrm{SO}_{4}{ }^{2-}, 1979-81 \\
\mathrm{SO}_{4}^{4-}, 1970-74\end{array}$} & \multicolumn{2}{|c|}{$\begin{array}{l}\mathrm{SO}_{4}{ }^{2-}, 1970-74 \\
\mathrm{SO}_{4}^{4-}, 1960-64\end{array}$} & \multicolumn{2}{|c|}{$\begin{array}{l}\mathrm{SO}_{4}{ }^{2-}, 1979-81 \\
\mathrm{SO}_{4}^{4-}, 1960-64\end{array}$} & \multicolumn{2}{|c|}{$\begin{array}{l}\mathrm{SO}_{4}{ }^{2-}, 1979-81 \\
\mathrm{FinSO}_{4}{ }^{2-}, 79-84\end{array}$} \\
\hline Ages 15-44 & 0.0087 & 0.0117 & 0.0194 & 0.0122 & $0.0332^{*}$ & 0.0105 & 0.0120 & 0.0148 & 0.0063 & 0.0173 & 0.0191 & 0.0148 & 0.0117 & 0.0333 \\
\hline Ages $45-64$ & $0.0320 *$ & 0.0086 & $0.0234^{*}$ & 0.0092 & $0.0216^{*}$ & 0.0080 & $0.0330^{*}$ & 0.0109 & $0.0442 *$ & 0.0117 & $0.0322 *$ & 0.0108 & $0.0552^{*}$ & 0.0195 \\
\hline Ages $65-74$ & $0.0441^{*}$ & 0.0067 & $0.0248^{*}$ & 0.0071 & 0.0095 & 0,0065 & $0.0377^{*}$ & 0.0082 & $0.0359^{*}$ & 0.0094 & $0.0235^{*}$ & 0.0083 & $0.0609^{*}$ & 0.0111 \\
\hline Ages $75-84$ & $0.0379 *$ & 0.0058 & $0.0226 *$ & 0.0058 & $0.0162^{*}$ & 0.0054 & $0.0309^{*}$ & 0.0069 & $0.0332 *$ & 0.0081 & 0.0301 * & 0.0068 & $0.0491^{*}$ & 0.0104 \\
\hline Ages $\geqslant 85$ & $0.0175^{*}$ & 0.0057 & $0.0184^{*}$ & 0.0057 & $0.0196 *$ & 0.0044 & $0.0155^{*}$ & 0.0065 & $0.0194^{*}$ & 0.0063 & $0.0224^{*}$ & 0.0059 & 0.0171 & 0.0097 \\
\hline \multirow[t]{2}{*}{ Log mean } & $0.0189 *$ & 0.0054 & 0.0103 & 0.0056 & $0.0121 *$ & 0.0044 & $0.0130^{*}$ & 0.0067 & $0.0147^{*}$ & 0.0071 & $0.0142^{*}$ & 0.0062 & $0.0258^{*}$ & 0.0088 \\
\hline & \multicolumn{2}{|c|}{$\begin{array}{l}\mathrm{SO}_{2,}, 1979-81 \\
\text { All locations }\end{array}$} & \multicolumn{2}{|c|}{$\begin{array}{l}\mathrm{SO}_{2}, 1970-74 \\
\text { All locations }\end{array}$} & \multicolumn{2}{|c|}{$\begin{array}{l}\mathrm{SO}_{2}, 1960-64 \\
\text { All locations }\end{array}$} & $\begin{array}{l}\mathrm{SO}_{2}, 1979 \\
\mathrm{SO}_{2}, 1970\end{array}$ & & $\begin{array}{l}\mathrm{SO}_{2}, 1979 \\
\mathrm{SO}_{2}, 1960\end{array}$ & & $\begin{array}{l}\mathrm{SO}_{2}, 1970- \\
\mathrm{SO}_{2}, 1960-\end{array}$ & & & \\
\hline Ages $15-44$ & 0.0210 & 0.0133 & 0.0204 & 0.0133 & $0.1778^{*}$ & 0.0412 & 0.0183 & 0.0177 & $0.1847^{\star}$ & 0.0465 & 0.0911 * & 0.0332 & & \\
\hline Ages $45-64$ & $0.0379 *$ & 0.0094 & 0.0094 & 0.0099 & 0.0034 & 0.0373 & $0.0390^{*}$ & 0.0123 & 0.0333 & 0.0389 & -0.0037 & 0.0270 & & \\
\hline Ages $65-74$ & $0.0202 *$ & 0.0086 & 0.0034 & 0.0081 & 0.0081 & 0.0223 & 0.0117 & 0.0107 & 0.0176 & 0.0233 & 0.0114 & 0.0160 & & \\
\hline Ages $75-84$ & $0.0233^{*}$ & 0.0073 & 0.0052 & 0.0068 & -0.0027 & 0.0150 & 0.0126 & 0.0093 & 0.0200 & 0.0161 & 0.0021 & 0.0099 & & \\
\hline Ages $\geqslant 85$ & $0.0263^{*}$ & 0.0073 & $0.0236^{*}$ & 0.0073 & 0.0354 & 0.0198 & $0.0347^{*}$ & 0.0095 & $0.0484^{*}$ & 0.0213 & $0.0439 *$ & 0.0120 & & \\
\hline Log mean & $0.0225^{*}$ & 0.0064 & $0.0138^{*}$ & 0.0061 & 0.0348 & 0.0192 & $0.0185^{*}$ & 0.0081 & $0.0541^{*}$ & 0.0198 & $0.0386^{*}$ & 0.0119 & & \\
\hline & $\begin{array}{l}\mathrm{NO}_{2}, 1979- \\
\text { All location }\end{array}$ & & $\begin{array}{l}\mathrm{NO}_{2} 1970- \\
\text { All location }\end{array}$ & & $\begin{array}{l}\mathrm{NO}_{2,1} 1960 \\
\text { All locatio }\end{array}$ & & & & & & & & & \\
\hline Ages $15-44$ & 0.0394 & 0.0235 & 0.0280 & 0.0309 & -0.0737 & 0.1158 & & & & & & & & \\
\hline Ages $45-64$ & 0.0186 & 0.0174 & 0.0162 & 0.0219 & -0.0567 & 0.0972 & & & & & & & & \\
\hline Ages $65-74$ & -0.0198 & 0.0134 & $-0.0346 *$ & 0.0178 & -0.0329 & 0.0481 & & & & & & & & \\
\hline Ages $75-84$ & -0.0205 & 0.0110 & -0.0256 & 0.0150 & 0.0038 & 0.0310 & & & & & & & & \\
\hline Ages $\geqslant 85$ & $0.0235^{*}$ & 0.0098 & 0.0037 & 0.0123 & 0.0475 & 0.0257 & & & & & & & & \\
\hline Log mean & 0.0120 & 0.0100 & -0.0117 & 0.0120 & $-0.1785^{*}$ & 0.0428 & & & & & & & & \\
\hline
\end{tabular}




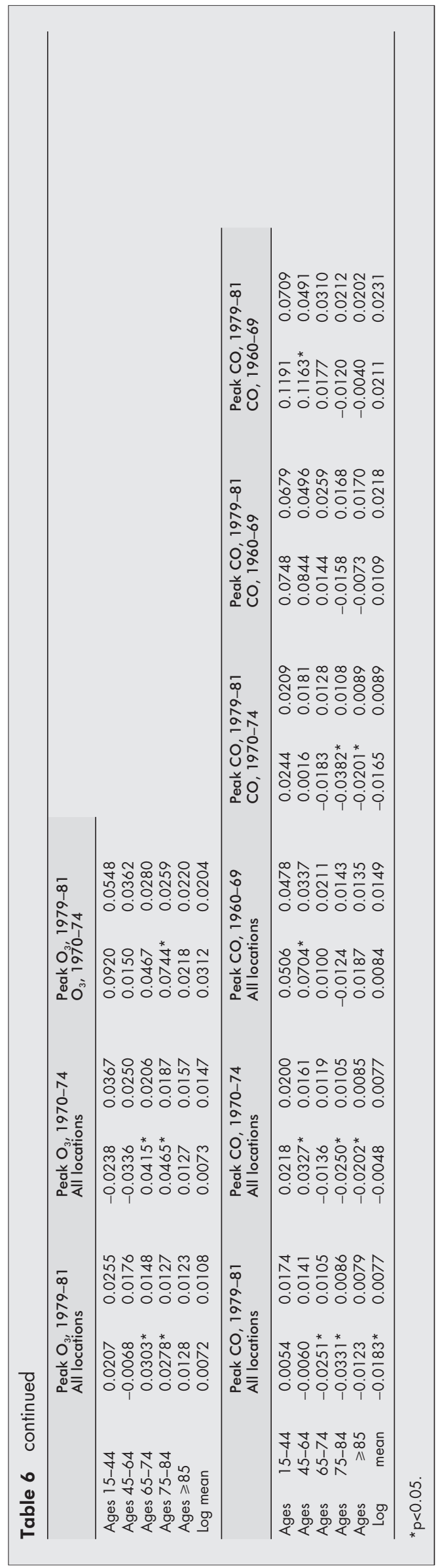

in some cases, measurement technology. Presentation of such a large correlation matrix here in its entirety is impractical; instead, the basic relations are described here with additional detail provided in the appendix. Of 80 correlations between pollutants for different periods, the highest value was 0.83 and only five values exceeded 0.5. Two of these are for $\mathrm{SO}_{4}{ }^{2-}$ versus $\mathrm{SO}_{2}$ (for 1960-64 and 1989-91); this relation may be influenced by artifact $\mathrm{SO}_{4}{ }_{4}^{2-}$ formed on the sampling filter from $\mathrm{SO}_{2}$ in the air passing through.

Correlations between periods tended to be higher for most pollutants, but they decrease with increasing time intervals between periods. For an interval of 10 years, the average correlations between periods ranged from 0.58 for $\mathrm{CO}$ to 0.82 for $\mathrm{SO}_{4}^{2-}$. For effects of measurement technology, the correlation between $\mathrm{SO}_{4}^{2-}$ measured in the IP network (1979-1984) and $\mathrm{SO}_{4}^{2-}$ measured by AIRS from 1979-81 is only 0.75, which reflects uncertainties associated primarily with the types of sampling filters used in the two networks. The VMTG had the highest correlations with $\mathrm{NO}_{2}$, in the range $0.55-0.64$. Correlations between different pollutants and different periods were thought to be generally smaller than those already described and were not considered in detail.

\section{Regression models}

Typically, each regression model used from eight to 15 variables and explained from $10 \%$ to $70 \%$ of the variance in mortality. Fewer variables (and less explanatory power) were found for the 85 and over age group; more independent variables and better fits were found for the log mean mortality variables. Race was the most important variable for all but the oldest age groups, followed by variables in education and population change. Smoking was important for ages 45-85; lack of exercise was important after about the age of 65 . Binge drinking (which also serves as an indicator variable for alcohol consumption in general) tended to indicate increased mortality for the younger age groups and reduced mortality for elderly people. Obesity did not play a part in these models, presumably because of collinearity with other variables. Unemployment was associated with increased mortality as were population density and residential air conditioning. Increased wind speed was associated with reduced mortality, but there were no indications of excessive collinearity between wind speed and air quality, with the possible exception of $\mathrm{SO}_{2}$ (presumably because daily variation was not considered). Note that wind speed (ventilation) will tend to affect primary and secondary pollutants differently, and will also affect airborne allergens and other unmeasured air pollutants. In general, the distributions of residuals from these models seemed to be essentially normal with a few positive outliers, especially for the older age groups.

Regression results are presented in tables 4-8. Concurrent exposures are considered at the left of each table, with results for successively increasing lag between exposure and response proceeding from left to right (tables 5-8). Then, results are considered for subsets restricted to counties with data for selected pollutants in specific periods, as indicated in the second line of headings in each section of the table.

\section{0-4}

This period, the earliest considered, predates the environmental movement that resulted in widespread improvements in air quality in the United States. It also predates the growth of health concerns about smoking, diet, and exercise. Air quality monitoring was mainly concerned with PM, which was monitored as TSP in 279 counties during the period. Sulfate concentrations were measured in 191 counties, but gaseous pollutant measurements were much more sparse. Regression results from this period are presented in table 4 . The ozone risks are based on 1970-74 data, under the assumption that 
Table 7 Attributable risks of mortality (1989-91) from different air quality variables

\begin{tabular}{|c|c|c|c|c|c|c|c|c|c|c|c|c|c|c|}
\hline & \multicolumn{2}{|c|}{$\begin{array}{l}\text { PM } 10,1989-91 \\
\text { All locations }\end{array}$} & \multicolumn{2}{|c|}{$\begin{array}{l}\text { TSP, 1989-91 } \\
\text { All locations }\end{array}$} & \multicolumn{2}{|c|}{$\begin{array}{l}\text { TSP, 1979-81 } \\
\text { All locations }\end{array}$} & \multicolumn{2}{|c|}{$\begin{array}{l}\text { TSP, 1970-74 } \\
\text { All locations }\end{array}$} & \multicolumn{2}{|c|}{$\begin{array}{l}\text { TSP, 1960-64 } \\
\text { All locations }\end{array}$} & & & & \\
\hline & Risk & SE & Risk & SE & Risk & SE & Risk & SE & Risk & SE & & & & \\
\hline Ages $15-44$ & -0.0065 & 0.0368 & 0.0104 & 0.0285 & 0.0112 & 0.0242 & -0.0050 & 0.0169 & 0.0344 & 0.0344 & & & & \\
\hline Ages $45-64$ & 0.0061 & 0.0206 & -0.0282 & 0.0175 & -0.0031 & 0.0148 & 0.0023 & 0.0101 & $0.0619^{*}$ & 0.0173 & & & & \\
\hline Ages $65-74$ & $-0.0245^{*}$ & 0.0152 & $-0.0328^{*}$ & 0.0138 & 0,0038 & 0.0115 & 0.0057 & 0.0082 & 0.0124 & 0.0126 & & & & \\
\hline Ages $76-84$ & 0.0149 & 0.0125 & $-0.0254^{*}$ & 0.0108 & 0.0080 & 0.0094 & 0.0006 & 0.0067 & 0.0062 & 0.0102 & & & & \\
\hline Ages $\geqslant 85$ & $0.0312^{*}$ & 0.0106 & -0.0064 & 0.0090 & 0.0071 & 0.0081 & 0.0011 & 0.0059 & 0.0152 & 0.0084 & & & & \\
\hline \multirow[t]{2}{*}{ Log mean } & -0.0017 & 0.0115 & -0.0088 & 0.0093 & 0.0091 & 0.0085 & -0.0003 & 0.0062 & 0.0116 & 0.0097 & & & & \\
\hline & \multicolumn{2}{|c|}{$\begin{array}{l}\mathrm{PM}_{2.5}, 1979-84 \\
\text { Alllocations }\end{array}$} & \multicolumn{2}{|l|}{$\begin{array}{l}\mathrm{PM}_{2.5}, 1999 \\
\text { Allocations }\end{array}$} & \multicolumn{2}{|c|}{$\begin{array}{l}\mathrm{PM}_{10,} 1999 \\
\text { Allocations }\end{array}$} & \multicolumn{2}{|c|}{$\begin{array}{l}\mathrm{PM}_{2.5}, 1999 \\
1979-84 \mathrm{PM}_{2.5}\end{array}$} & \multicolumn{2}{|c|}{$\begin{array}{l}\mathrm{PM}_{2 \cdot 5^{\prime}} 19999 \\
1960^{-64} \mathrm{TSP}\end{array}$} & & & & \\
\hline Ages $15-44$ & 0.0998 & 0.0936 & -0.0353 & 0.0331 & -0.0408 & 0.0365 & 0.1497 & 0.0980 & 0.0741 & 0.0554 & & & & \\
\hline Ages $45-64$ & $0.1520^{*}$ & 0.0466 & $0.0500^{*}$ & 0.0187 & 0.0263 & 0.0206 & $0.1583^{*}$ & 0.0483 & $0.1099^{*}$ & 0.0300 & & & & \\
\hline Ages $65-74$ & $0.0708^{*}$ & 0.0238 & $0.0525^{*}$ & 0.0147 & -0.0070 & 0.0167 & $0.0544^{*}$ & 0.0255 & $0.0500^{*}$ & 0.0191 & & & & \\
\hline Ages $75-84$ & $0.0385^{*}$ & 0.0199 & $0.0373^{*}$ & 0.0118 & 0.0039 & 0.0137 & $0.0425^{*}$ & 0.0203 & $0.0303^{*}$ & 0.0150 & & & & \\
\hline Ages $\geqslant 85$ & $0.0400^{*}$ & 0.0161 & $0.0468^{*}$ & 0.0098 & 0.0209 & 0.0107 & $0.0628^{*}$ & 0.0161 & $0.0564^{*}$ & 0.0123 & & & & \\
\hline \multirow[t]{2}{*}{ Log mean } & $0.0458^{*}$ & 0.0229 & 0.0052 & 0.0104 & -0.0070 & 0.0116 & $0.0557^{*}$ & 0.0233 & 0.0311 * & 0.0156 & & & & \\
\hline & \multicolumn{2}{|c|}{$\begin{array}{l}\mathrm{SO}_{4}{ }^{2-}, 1982-88 \\
\text { Allocations }\end{array}$} & \multicolumn{2}{|c|}{$\begin{array}{l}\mathrm{SO}_{4}{ }^{2-}, 1979-81 \\
\text { Alllocations }\end{array}$} & \multicolumn{2}{|c|}{$\begin{array}{l}\mathrm{SO}_{4}{ }^{2-}, 1970-74 \\
\text { Allocations }\end{array}$} & \multicolumn{2}{|c|}{$\begin{array}{l}\mathrm{SO}_{4}{ }^{2-}, 1960-64 \\
\text { Alllocations }\end{array}$} & \multicolumn{2}{|c|}{$\begin{array}{l}\text { Fine } \mathrm{SO}_{4}{ }^{2-}, 1979-84 \\
\text { Alllocations }\end{array}$} & \multicolumn{2}{|c|}{$\begin{array}{l}\mathrm{SO}_{4}{ }^{2-}, 1982-88 \\
\text { fine } \mathrm{SO}_{4}{ }^{2-}, 79-84\end{array}$} & \multicolumn{2}{|c|}{$\begin{array}{l}\mathrm{SO}_{4}{ }^{2-}, 1979-81 \\
\text { fine } \mathrm{SO}_{4}{ }^{2-}\end{array}$} \\
\hline Ages $15-44$ & -0.0112 & 0.0095 & -0.0037 & 0.0173 & $0.0353^{*}$ & 0.0177 & $0.0539 *$ & 0.0164 & $0.1522^{*}$ & 0.0665 & 0.0446 & 0.0351 & 0.0657 & 0.0568 \\
\hline Ages $45-64$ & $0.0150 *$ & 0.0058 & 0.0321 * & 0.0092 & 0.0391 * & 0.0099 & $0.0323^{*}$ & 0.0080 & $0.1218^{*}$ & 0.0313 & $0.0335^{*}$ & 0.0155 & $0.0466 *$ & 0.0253 \\
\hline Ages $65-74$ & $0.0130^{*}$ & 0.0037 & 0.0220 * & 0.0062 & $0.0183^{*}$ & 0.0064 & 0.0090 & 0.0054 & $0.0590^{*}$ & 0.0159 & $0.0225^{*}$ & 0.0095 & $0.0379 *$ & 0.0113 \\
\hline Ages $75-84$ & $0.0097^{*}$ & 0.0029 & $0.0187^{*}$ & 0.0051 & $0.0115^{*}$ & 0.0050 & 0.0009 & 0.0042 & $0.0383^{*}$ & 0.0131 & $0.0186^{*}$ & 0.0081 & $0.0304^{*}$ & 0.0095 \\
\hline Ages $\geqslant 85$ & $0.0073^{*}$ & 0.0026 & $0.0180 *$ & 0.0042 & $0.0169^{*}$ & 0.0047 & 0.0106 * & 0.0034 & $0.0323^{*}$ & 0.0099 & 0.0102 & 0.0063 & $0.0174^{*}$ & 0.0077 \\
\hline \multirow[t]{2}{*}{ Log mean } & -0.0042 & 0.0032 & -0.0000 & 0.0050 & 0.0044 & 0.0053 & $0.0084^{*}$ & 0.0042 & $0.0492^{*}$ & 0.0161 & -0.0042 & 0.0032 & 0.0172 & 0.0126 \\
\hline & \multicolumn{2}{|c|}{$\begin{array}{l}\mathrm{SO}_{2,}, 1989-91 \\
\text { Alllocations }\end{array}$} & \multicolumn{2}{|c|}{$\begin{array}{l}\mathrm{SO}_{2,}, 1979-81 \\
\text { Alllocations }\end{array}$} & \multicolumn{2}{|c|}{$\begin{array}{l}\mathrm{SO}_{2}, 1970-74 \\
\text { Allocations }\end{array}$} & \multicolumn{2}{|c|}{$\begin{array}{l}\mathrm{SO}_{2,}, 1960-69 \\
\text { Allocations }\end{array}$} & & & & & & \\
\hline Ages $15-44$ & 0.0276 & 0.0215 & $0.0441^{*}$ & 0.0193 & $0.0594^{*}$ & 0.0195 & $0.2469^{*}$ & 0.0625 & & & & & & \\
\hline Ages $45-64$ & $0.0329 *$ & 0.0114 & $0.0309^{*}$ & 0.0102 & $0.0337^{*}$ & 0.0103 & 0.0199 & 0.0366 & & & & & & \\
\hline Ages $65-74$ & 0.0271 * & 0.0087 & $0.0177^{*}$ & 0.0078 & 0.0134 & 0.0073 & -0.0131 & 0.0166 & & & & & & \\
\hline Ages $76-84$ & 0.0151 * & 0.0076 & 0.0114 & 0.0087 & -0.0015 & 0.0065 & -0.0154 & 0.0136 & & & & & & \\
\hline Ages $\geqslant 85$ & $0.0179 *$ & 0.0016 & $0.0152^{*}$ & 0.0054 & 0.0055 & 0.0050 & 0.0118 & 0.0130 & & & & & & \\
\hline Log mean & $0.0172^{*}$ & 0.0068 & 0.0108 & 0.0061 & $0.0177^{*}$ & 0.0063 & 0.0192 & 0.0159 & & & & & & \\
\hline & $\begin{array}{l}\mathrm{NO}_{2}, 1989 \\
\text { Allocations }\end{array}$ & & $\begin{array}{l}\mathrm{NO}_{2}, 1979 \\
\text { Alllocations }\end{array}$ & & $\begin{array}{l}\mathrm{NO}_{2}, 197 \mathrm{C} \\
\text { Alllocation }\end{array}$ & & $\begin{array}{l}\mathrm{NO}_{2}, 1960 \\
\text { Alllocation }\end{array}$ & & & & & & & \\
\hline Ages $15-44$ & $0.1370^{*}$ & 0.0400 & $0.1021^{*}$ & 0.0341 & $0.1466 *$ & 0.0430 & 0.2545 & 0.1527 & & & & & & \\
\hline Ages $45-64$ & $0.0840^{*}$ & 0.0211 & $0.0656^{*}$ & 0.0187 & 0.0395 & 0.0219 & 0.0422 & 0.0872 & & & & & & \\
\hline Ages $65-74$ & 0.0047 & 0.0142 & -0.0032 & 0.0133 & -0.0098 & 0.0137 & 0.0134 & 0.0365 & & & & & & \\
\hline Ages $75-84$ & -0.0210 & 0.0123 & $-0.0221^{*}$ & 0.0094 & $-0.0315^{*}$ & 0.0117 & -0.0192 & 0.0270 & & & & & & \\
\hline Ages $\geqslant 85$ & 0.0144 & 0.0091 & 0.0018 & 0.0072 & $-0.0479 *$ & 0.0083 & 0.0226 & 0.0245 & & & & & & \\
\hline Log mean & 0.0241 * & 0.0113 & 0.0179 & 0.0100 & 0.0098 & 0.0123 & -0.0275 & 0.0428 & & & & & & \\
\hline
\end{tabular}




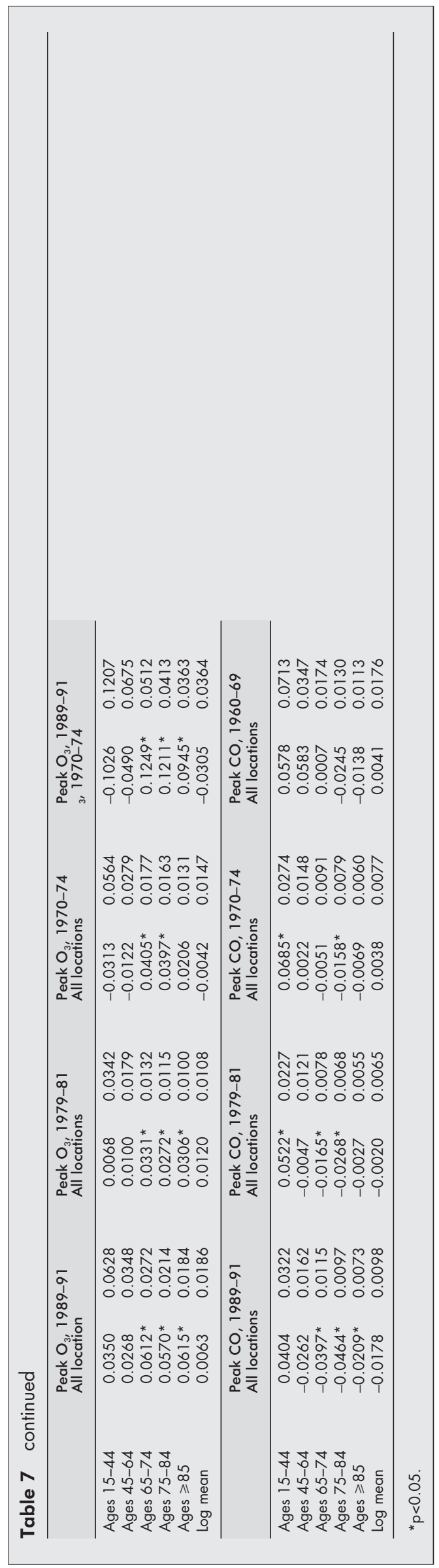

the spatial distribution of ozone may not have changed appreciably from the 1960s to the 1970s. Except for ozone, the largest risks were found in the youngest age group, and the risks tend to decrease with age. Note the absence of increased mortality in the $\geqslant 85$ age group. For log-mean mortality, the largest risks were found for $\mathrm{NO}_{2}$ (which was not significant, probably because only 33 counties had data), TSP, and $\mathrm{SO}_{2}$, with $\mathrm{CO}$ close behind, all at about $4 \%$. Note that the national averages of TSP, $\mathrm{SO}_{2}$ and $\mathrm{CO}$ during this period exceeded the ambient air quality standards that were established in the 1970s.

Dose-response characteristics are considered in figure 1 for TSP, $\mathrm{SO}_{4}^{2-}, \mathrm{SO}_{2}$ and peak CO. The plot for $\mathrm{NO}_{2}$ (not shown) had a great deal of scatter, except for ages $15-44$. As these plots are based on residuals from national models, they may not be centred on the zero axis; such offsets indicate that mortality in the counties with air quality differed from the national average and thus from those lacking such monitoring. Figure 1 A suggests a TSP break point at about $100-110 \mu \mathrm{g} / \mathrm{m}^{3}$, well above the previous standard of $75 \mu \mathrm{g} / \mathrm{m}^{3}$, but segmented regression analysis suggested that the threshold might be as high as $135 \mu \mathrm{g} / \mathrm{m}^{3}$ for this dataset. Possible thresholds are less apparent for $\mathrm{SO}_{4}^{2-}$ (fig l B), and only ages 15-44 and 75-84 showed steady increases in mortality with increasing pollution (note that this plot has been adjusted for $\mathrm{SO}_{4}^{2-}$ filter artifacts). Thus, a significant regression coefficient does not always imply a credible dose-response relation (ages 45-64, 65-74). For $\mathrm{SO}_{2}$ (fig l C) and CO (fig l D), for which 1960-69 data were used, only the 15-44 age group showed responses that increased substantially with pollution, but there were suggestions of thresholds at 20-40 $\mathrm{ppb} \mathrm{SO}_{2}$ and 10-15 ppm (95th percentile) CO. The log mean mortality plots (not shown) suggest a TSP threshold at about $110 \mu \mathrm{g} / \mathrm{m}^{3}$, for CO at about $17 \mathrm{ppm}$, for $\mathrm{SO}_{4}{ }^{2-}$ at about $7.5 \mu \mathrm{g} / \mathrm{m}^{3}$ (including artifact), and about $25 \mathrm{ppb}$ for $\mathrm{SO}_{2}$.

\section{0-4}

Environmental monitoring coverage increased substantially during this period ( 1258 counties had TSP data) and air quality began to improve in major cities in response to emission controls and use of cleaner fuels. Including additional counties substantially reduced the SEs of the mortality regression coefficients. Regression results are given in table 5, for both concurrent and previous air quality measures. Most of the attributable risks decreased relative to the earlier period, which is partly due to improved air quality (note the large decrease in mean $\mathrm{SO}_{2}$ ). The TSP and $\mathrm{O}_{3}$ risks were highest for elderly people, but $\mathrm{CO}, \mathrm{NO}$, and $\mathrm{SO}_{2}$ showed the opposite trend, with $\mathrm{CO}$ and $\mathrm{NO}_{2}$ showing negative risks. Responses to $\mathrm{SO}_{4}{ }^{2-}$ were about the same for all ages. The log-mean mortality risk was significant only for $\mathrm{SO}_{2}$, at less than half of the 1960-64 risk estimate. When air quality from the previous period was considered, the risks were higher for TSP and $\mathrm{SO}_{2}$; this trend may either reflect delayed responses or differences in the locations with air monitoring data. The third set of data in table 5 represents concurrent (1970-74) measurements taken at the earlier locations (to the extent that the two sets overlap). This comparison suggests that the differences in implied risk relate more to location than to the timing of response with respect to exposure. Thus, although the expansion of air quality monitoring between the 1960s and 1970s increased the precision of the estimates through smaller SEs, it did not indicate generally larger risks of mortality.

\section{9-81}

The 1979-81 period is the first for which the IPN data that were used in other cross sectional studies ${ }^{4-632}$ are applicable. They are included in the regression results shown in table 6, in which responses to (concurrent) TSP became non-significant, $\mathrm{SO}_{4}{ }^{2-}$ and $\mathrm{SO}_{2}$ effects increased, $\mathrm{CO}$ and $\mathrm{NO}_{2}$ risks became more strongly negative (except for $\mathrm{NO}_{2}$ at age $\geqslant 85$ ), and $\mathrm{O}_{3}$ effects 
Table 8 Attributable risks of mortality (1995-97) from different air quality variables

\begin{tabular}{|c|c|c|c|c|c|c|c|c|c|c|c|c|c|c|}
\hline & \multicolumn{2}{|c|}{$\begin{array}{l}\mathrm{PM}_{10,1} \text { 1995-97 } \\
\text { All locations }\end{array}$} & \multicolumn{2}{|c|}{$\begin{array}{l}\mathrm{PM}_{10,1} \text { 1989-91 } \\
\text { All locations }\end{array}$} & \multicolumn{2}{|c|}{$\begin{array}{l}\mathrm{PM}_{10}, 1995-97 \\
\mathrm{TSP}_{1} 1960-64\end{array}$} & \multicolumn{2}{|c|}{$\begin{array}{l}\mathrm{PM}_{10}, 1989-91 \\
\mathrm{TSP}_{1} 1960-64\end{array}$} & \multicolumn{2}{|c|}{$\mathrm{PM}_{2.5}, 1999$ All locations } & \multicolumn{2}{|c|}{$\begin{array}{l}\mathrm{PM}_{2.5}, 1979-84 \\
\text { All locations }\end{array}$} & \multicolumn{2}{|c|}{$\begin{array}{l}\mathrm{PM}_{2.5}, 1999 \mathrm{PM}_{2.5} \\
1979-84\end{array}$} \\
\hline & Risk & SE & Risk & SE & Risk & SE & Risk & SE & Risk & SE & Risk & SE & Risk & SE \\
\hline Ages $15-44$ & -0.0074 & 0.0289 & 0.0311 & 0.0288 & $0.1055^{\star}$ & 0.0481 & 0.0895 & 0.0463 & 0.0391 & 0.0264 & 0.0806 & 0.0700 & 0.0634 & 0.0705 \\
\hline Ages $45-64$ & 0.0067 & 0.0219 & -0.0126 & 0.0175 & 0.0458 & 0.0371 & 0.0114 & 0.0293 & $0.0509 *$ & 0.0200 & $0.1038^{*}$ & 0.0523 & $0.1037^{*}$ & 0.0528 \\
\hline Ages $65-74$ & 0.0105 & 0.0192 & -0.0302 & 0.0146 & -0.0284 & 0.0265 & -0.0311 & 0.0201 & 0.0258 & 0.0170 & 0.0203 & 0.0266 & -0.0055 & 0.0287 \\
\hline Ages $76-84$ & -0.0100 & 0.0184 & $-0.0357^{*}$ & 0.0144 & -0.0373 & 0.0273 & -0.0601 * & 0.0212 & 0.0086 & 0.0174 & 0.0288 & 0.0363 & -0.0306 & 0.0352 \\
\hline Ages $\geqslant 85$ & -0.0025 & 0.0146 & -0.0106 & 0.0119 & -0.0090 & 0.0209 & -0.0167 & 0.0172 & 0.0084 & 0.0141 & 0.0299 & 0.0270 & 0.0017 & 0.0263 \\
\hline \multirow[t]{2}{*}{ Log mean } & -0.0014 & 0.0127 & -0.0104 & 0.0101 & 0.0125 & 0.0198 & 0.0012 & 0.0142 & 0.0215 & 0.0117 & 0.0248 & 0.0248 & 0.0091 & 0.0246 \\
\hline & \multicolumn{2}{|c|}{$\begin{array}{l}\text { TSP, 1989-91 } \\
\text { All locations }\end{array}$} & \multicolumn{2}{|c|}{$\begin{array}{l}\text { TSP, 1979-81 } \\
\text { All locations }\end{array}$} & \multicolumn{2}{|c|}{$\begin{array}{l}\text { TSP, 1970-74 } \\
\text { All locations }\end{array}$} & \multicolumn{2}{|c|}{$\begin{array}{l}\text { TSP, 1960-64 } \\
\text { II locations }\end{array}$} & \multicolumn{2}{|c|}{$\begin{array}{l}\text { TSP, 1979-81 } \\
\text { TSP, 1960-64 }\end{array}$} & & & & \\
\hline Ages 15-44 & 0.0318 & 0.0258 & 0.0345 & 0.0214 & 0.0085 & 0.0161 & $0.0538^{*}$ & 0.0263 & $0.0798^{*}$ & 0.0403 & & & & \\
\hline Ages 45-64 & -0.0104 & 0.0084 & 0.0 & 0.0057 & -0.0027 & 0.0037 & $0.0093^{*}$ & 0.0047 & 0.0031 & 0.0115 & & & & \\
\hline Ages $65-74$ & -0.0025 & 0.0072 & $0.0099 *$ & 0.0049 & 0.0042 & 0.0031 & 0.0048 & 0.0035 & 0.0077 & 0.0086 & & & & \\
\hline Ages $75-84$ & -0.0080 & 0.0068 & 0.0091 * & 0.0045 & 0.0030 & 0.0029 & 0.0042 & 0.0035 & 0.0051 & 0.0085 & & & & \\
\hline Ages $\geqslant 85$ & -0.0066 & 0.0057 & 0.0026 & 0.0040 & 0.0005 & 0.0025 & $0.0087^{*}$ & 0.0027 & 0.0060 & 0.0067 & & & & \\
\hline \multirow[t]{2}{*}{ Log mean } & -0.0009 & 0.0060 & $0.0068^{*}$ & 0.0033 & 0.0006 & 0.0022 & $0.0061^{*}$ & 0.0026 & -0.0073 & 0.0064 & & & & \\
\hline & \multicolumn{2}{|c|}{$\begin{array}{l}\mathrm{SO}_{4}{ }_{4}^{2-}, 1982-88 \\
\text { All locations }\end{array}$} & \multicolumn{2}{|c|}{$\begin{array}{l}\text { Fine } \mathrm{SO}_{4}{ }^{2-}, 79-84 \\
\text { All locations }\end{array}$} & \multicolumn{2}{|c|}{$\begin{array}{l}\mathrm{SO}_{4}{ }^{2-}, 1979-81 \\
\text { All locations }\end{array}$} & \multicolumn{2}{|c|}{$\begin{array}{l}\mathrm{SO}_{4}{ }_{4}^{2-}, 1970-74 \\
\text { All locations }\end{array}$} & \multicolumn{2}{|c|}{$\begin{array}{l}\mathrm{SO}_{4}{ }^{2-}, 1960-64 \\
\text { All locations }\end{array}$} & \multicolumn{2}{|c|}{$\begin{array}{l}\mathrm{SO}_{4}{ }^{2-}, 1979-81 \\
\text { fin } \mathrm{SO}_{4}^{2-}, 79-84\end{array}$} & & \\
\hline Ages 15-44 & -0.0191 * & 0.0080 & 0.0775 & 0.0465 & -0.0188 & 0.0131 & 0.0067 & 0.0138 & $0.0438^{*}$ & 0.0122 & 0.0444 & 0.0376 & & \\
\hline Ages $45-64$ & 0.0116 & 0.0063 & $0.0992 *$ & 0.0340 & 0.0129 & 0.0102 & $0.0266^{*}$ & 0.0108 & 0.0381 * & 0.0087 & 0.0413 & 0.0281 & & \\
\hline Ages $65-74$ & $0.0197^{*}$ & 0.0040 & $0.0484^{*}$ & 0.0189 & 0.0135 & 0.0072 & 0.0032 & 0.0074 & 0.0003 & 0.0062 & $0.0304^{*}$ & 0.0148 & & \\
\hline Ages $75-84$ & 0.0230 * & 0.0037 & 0.0427 & 0.0236 & $0.0210^{*}$ & 0.0071 & -0.0010 & 0.0072 & -0.0045 & 0.0066 & $0.0516^{*}$ & 0.0157 & & \\
\hline Ages $\geqslant 85$ & $0.0107^{*}$ & 0.0033 & $0.0459^{*}$ & 0.0164 & $0.0173^{*}$ & 0.0053 & 0.0104 & 0.0056 & $0.0142 *$ & 0.0047 & $0.0363^{*}$ & 0.0103 & & \\
\hline \multirow[t]{2}{*}{ Log mean } & 0.0018 & 0.0030 & $0.0440 *$ & 0.0155 & -0.0025 & 0.0054 & -0.0036 & 0.0058 & $0.0099 *$ & 0.0047 & $0.0243^{*}$ & 0.0096 & & \\
\hline & \multicolumn{2}{|c|}{$\begin{array}{l}\mathrm{SO}_{2,1} 1995-97 \\
\text { All locations }\end{array}$} & \multicolumn{2}{|c|}{$\begin{array}{l}\mathrm{SO}_{2,} \text { 1989-91 } \\
\text { All locations }\end{array}$} & \multicolumn{2}{|c|}{$\begin{array}{l}\mathrm{SO}_{2}, 1979-81 \\
\text { All locations }\end{array}$} & $\begin{array}{l}\mathrm{SO}_{2}, 1970- \\
\text { All location }\end{array}$ & & $\begin{array}{l}\mathrm{SO}_{2}, 1960 \\
\text { All location }\end{array}$ & & $\begin{array}{l}\mathrm{SO}_{2}, 1995- \\
\mathrm{SO}_{2}, 1970-\end{array}$ & & $\begin{array}{l}\mathrm{SO}_{2}, 1989- \\
\mathrm{SO}_{2}, 1970\end{array}$ & \\
\hline Ages $15-44$ & -0.0080 & 0.0187 & 0.0187 & 0.0163 & 0.0263 & 0.0143 & $0.0337^{*}$ & 0.0155 & 0.0722 & 0.0499 & 0.0067 & 0.0274 & 0.0302 & 0.0253 \\
\hline Ages 45-64 & -0.0002 & 0.0134 & 0.0169 & 0.0123 & 0.0339 * & 0.0107 & $0.0446^{*}$ & 0.0177 & 0.0524 & 0.0416 & 0.0148 & 0.0211 & $0.0633^{*}$ & 0.0195 \\
\hline Ages $65-74$ & 0.0168 & 0.0107 & 0.0072 & 0.0097 & 0.0122 & 0.0091 & 0.0079 & 0.0087 & -0.0213 & 0.0196 & -0.0109 & 0.0141 & 0.0047 & 0.0131 \\
\hline Ages $75-84$ & 0.0126 & 0.0115 & 0.0102 & 0.0100 & 0.0096 & 0.0087 & 0.0046 & 0.0096 & -0.0006 & 0.0261 & 0.0061 & 0.0155 & 0.0073 & 0.0146 \\
\hline Ages $\geqslant 85$ & 0.0311 * & 0.0084 & $0.0218^{*}$ & 0.0077 & 0.0102 & 0.0066 & 0.0050 & 0.0064 & 0.0236 & 0.0180 & 0.0156 & 0.0106 & 0.0145 & 0.0100 \\
\hline Log mean & 0.0148 & 0.0079 & 0.0143 & 0.0129 & 0.0126 * & 0.0063 & 0.0161 * & 0.0063 & 0.0110 & 0.0164 & -0.0049 & 0.0108 & 0.0093 & 0.0100 \\
\hline & $\begin{array}{l}\mathrm{NO}_{2}, 1995 \\
\text { All location }\end{array}$ & & $\begin{array}{l}\mathrm{NO}_{2}, 1989 \\
\text { All location }\end{array}$ & & $\begin{array}{l}\mathrm{NO}_{2}, 1979 \\
\text { All location }\end{array}$ & & $\begin{array}{l}\mathrm{NO}_{2}, 1970 \\
\text { All location }\end{array}$ & & $\begin{array}{l}\mathrm{NO}_{2}, 1960 \\
\text { All location }\end{array}$ & & $\begin{array}{l}\mathrm{NO}_{2}, 1995 \\
\mathrm{PM}_{2.5}, 1979\end{array}$ & & & \\
\hline Ages 15-44 & $0.1304^{*}$ & 0.0250 & $0.1248^{*}$ & 0.0267 & $0.1165^{*}$ & 0.0244 & $0.1177^{*}$ & 0.0315 & 0.0403 & 0.1116 & $0.1791^{*}$ & 0.0604 & & \\
\hline Ages 45-64 & 0.1070 * & 0.0190 & $0.1148^{*}$ & 0.0227 & 0.0974 * & 0.0202 & $0.0830 *$ & 0.0239 & 0.0642 & 0.0969 & $0.1444^{*}$ & 0.0438 & & \\
\hline Ages $65-74$ & -0.0279 & 0.0149 & -0.0222 & 0.0173 & -0.0217 & 0.0152 & -0.0234 & 0.0173 & -0.0026 & 0.0388 & -0.0232 & 0.0202 & & \\
\hline Ages 75-84 & $-0.0599 *$ & 0.0161 & $-0.0607^{*}$ & 0.0188 & $-0.0678^{*}$ & 0.0159 & $-0.0465^{*}$ & 0.0185 & -0.0261 & 0.0412 & $-0.0885^{*}$ & 0.0260 & & \\
\hline Ages $\geqslant 85$ & -0.0396 * & 0.0128 & $-0.0271^{*}$ & 0.0133 & $-0.0278^{*}$ & 0.0106 & -0.0187 & 0.0120 & -0.0027 & 0.0339 & $-0.0543^{*}$ & 0.0194 & & \\
\hline Log mean & 0.0101 & 0.0110 & 0.0155 & 0.0125 & $0.0239 *$ & 0.0108 & 0.0112 & 0.0126 & -0.0029 & 0.0357 & 0.0031 & 0.0184 & & \\
\hline
\end{tabular}

$p<0.05$. 


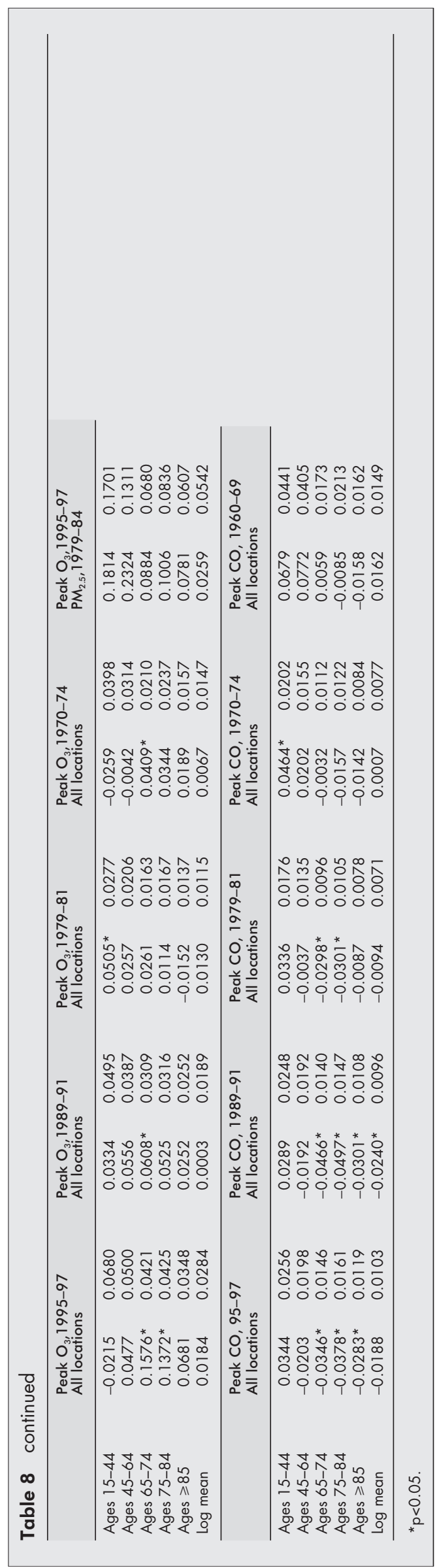

stayed at about the same level but with improved levels of significance. The 1979-84 IPN results showed the highest attributable risks, for $\mathrm{PM}_{2.5}$ and $\mathrm{SO}_{4}^{2-}$ (data from the fine particle fraction). The risks from $\mathrm{PM}_{15}$ were lower and largely non-significant; thus, coarse particles themselves were not considered. Again, higher risks were found in the younger age groups, but the risks for log-mean mortality were less than 0.06 .

Table 6 also considers risks attributed to earlier exposure to air pollution. Risks attributed to 1960-64 TSP were significant and exceeded the concurrent TSP risks, but this was not the case for $\mathrm{SO}_{4}^{2-}$, for which the locations monitored seemed to be more important than the timing. When the 1979-81 AIRS $\mathrm{SO}_{4}{ }^{2-}$ data (327 counties) were limited to the IPN locations (77 counties), the implied risks increased, but not quite to the higher levels of the IPN data themselves. For the gaseous pollutants, concurrent $\mathrm{SO}_{2}$ was significant, $\mathrm{NO}_{2}$ was mainly not significant, risks attributed to $\mathrm{O}_{3}$ were more important for earlier exposures and for elderly people, and CO risks were significant but negative (except for younger age groups and earlier exposures).

Figure 2 illustrates 1979-81 dose-response for concurrent $\mathrm{PM}_{2.5}$; the largest risks are for the younger age groups, with the suggestion of a threshold at about $19 \mu \mathrm{g} / \mathrm{m}^{3}$. The plots for elderly people seem to be nearly linear. Figure 3 shows 1979-81 risks attributed to $\mathrm{SO}_{4}{ }^{2-}$ as a function of age. For AIRS $\mathrm{SO}_{4}{ }^{2-}$ (corrected for artifact), the risks were generally lower for previous exposures. This suggests that, because of the high correlations between $\mathrm{SO}_{4}^{2-}$ measured in successive periods (typically arround 0.8 or more) delayed responses may be difficult to distinguish. Figure 3 also shows large differences between $\mathrm{SO}_{4}{ }^{2-}$ risks from AIRS and IPN, as also seen in table 6. The plots for AIRS $\mathrm{SO}_{4}^{2-}$ for $1970-74$ and 1979-81 are among the few that show peaks for elderly people.

We evaluated responses to traffic density by regressing national mortality residuals against VMTG, for both the full dataset and the restricted dataset defined by the IPN monitoring data. Such restriction made little difference. For 1979-81 mortality, significant positive effects of VMTG were found for ages $<65$ and a significant negative response was found for ages 75-84 (unrestricted data set only). The positive risks were in the range $0.07-0.10$.

\section{9-91}

Table 7 presents attributable risk estimates for 1989-91; these are thought to be the first published estimates for this period, which allows an overlap between the TSP data of earlier periods and the subsequent $\mathrm{PM}_{10}$ results. We also considered 1999 AIRS $\mathrm{PM}_{2.5}$ data, as already discussed. However, strictly concurrent $\mathrm{SO}_{4}^{2-}$ data were not available. Table 7 shows the largest risks to be associated with $\mathrm{PM}_{25}$ from the IPN, followed by AIRS $\mathrm{PM}_{2.5}$. For elderly people, peak $\mathrm{O}_{3}$ risks are similar. Risks attributed to either TSP or $\mathrm{PM}_{10}$ were generally less important, but $\mathrm{PM}_{10}$ seemed to be the better predictor, even though the correlation between TSP and $\mathrm{PM}_{10}$ was 0.58 . There is essentially no indication of persistent effects from earlier exposures to PM. Risks from $\mathrm{SO}_{2}$ were also lower than in previous periods for concurrent exposures and decreased further as older data were considered. For ages $<65 \mathrm{NO}_{2}$ was important, but not for elderly people. Theree were significant negative effects for $\mathrm{CO}$. Again, the risks attributed to $\mathrm{SO}_{4}{ }^{2-}$ were highly dependent upon the locations monitored, with the IPN data from the previous decade showing about twice the risk of the AIRS data (corrected for artifact). There was little difference among the AIRS datasets for different periods, but restricting the locations to correspond with the IPN again increased the estimates. The VMTG (not shown in table 7) was a significant positive predictor of mortality for ages 15-44, 45-64, and for the log mean mortality. However, VMTG was significantly negatively associated with mortality in those aged $75-84$. 

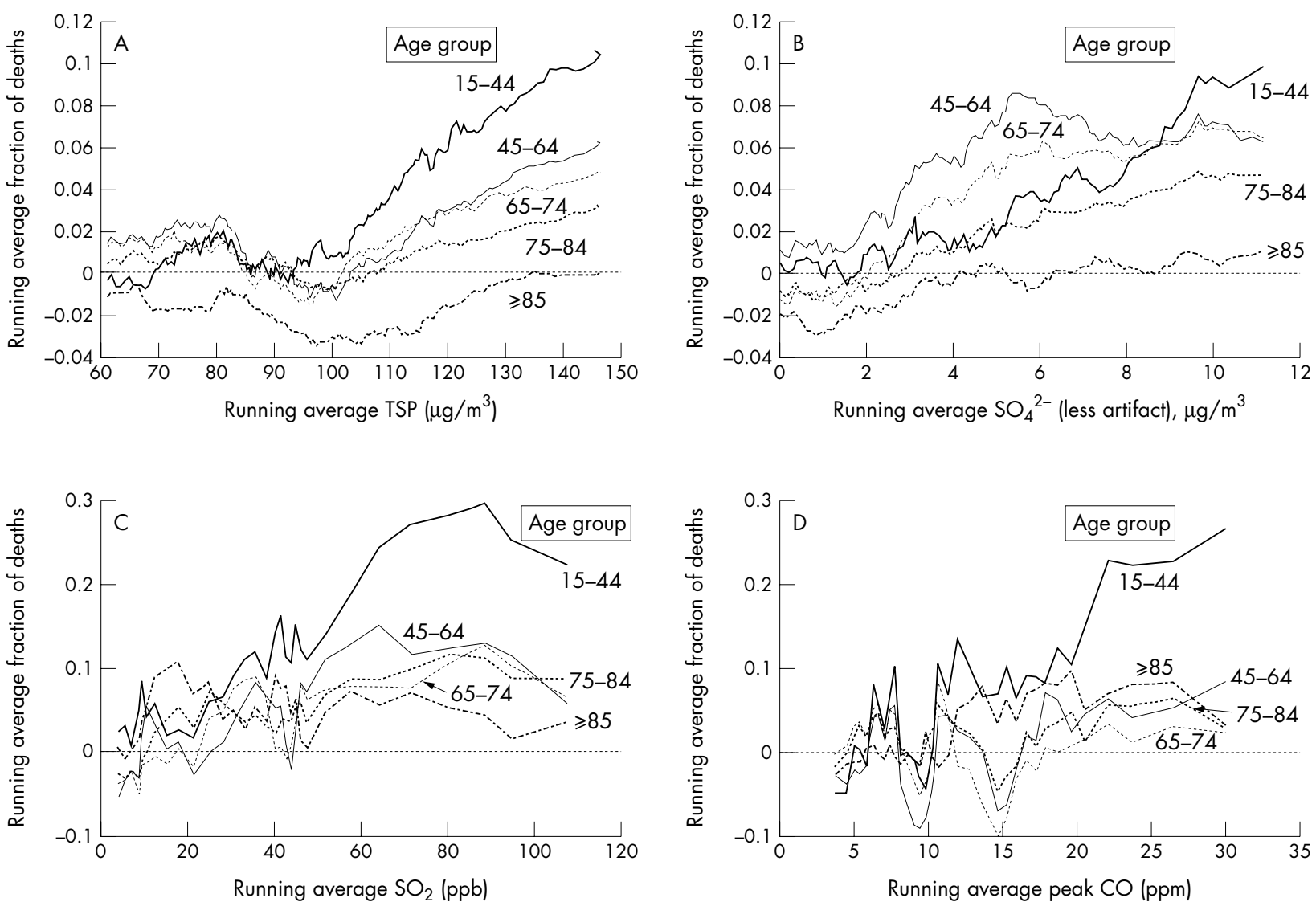

Figure 1 Smoothed dose-response curves for 1960-4 mortality by age group. (A) 1960-64 TSP. (B) 1960-64 SO ${ }_{4}^{2 .}$. (C) 1960-69 SO 2 . (D) 1960-69 95th percentile CO.

Age relations for $\mathrm{PM}_{2.5}$ and $\mathrm{SO}_{4}{ }^{2-}$ are shown in figure $4 \mathrm{~A}$ and $\mathrm{B}$, which illustrates another way to contrast the various air quality datasets. In figure $4 \mathrm{~A}$, large differences are seen for ages $<65$, but the implied modest risks for the elderly people are very consistent for all four datasets. The largest data set (1999 AIRS) shows the lowest risks for younger ages. Somewhat similar relations are seen for $\mathrm{SO}_{4}{ }^{2-}$ (fig $4 \mathrm{~B}$ ), with the IPN dataset again showing much larger risks for younger ages. Restricting the 1979-81 AIRS data to the IPN locations increased the implied risks, showing reasonable agreement for elderly people.

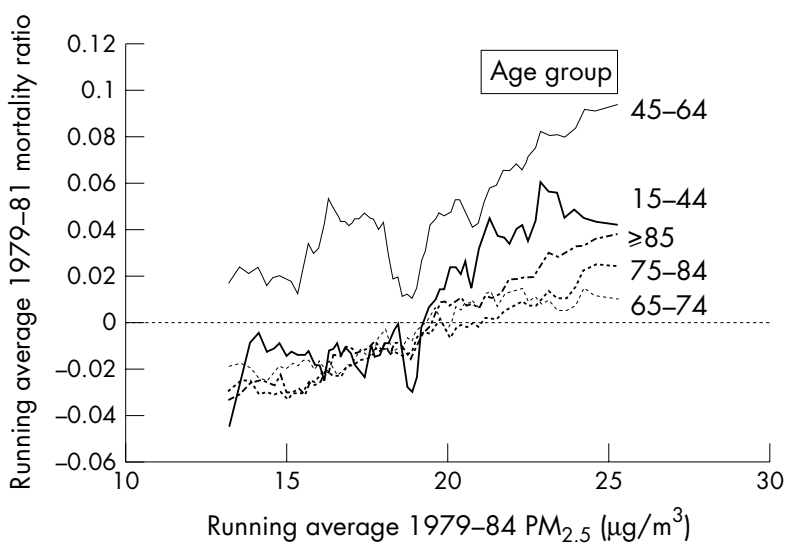

Figure 2 Smoothed dose-response curves for 1979-81 mortality by age group for $\mathrm{PM}_{25}$ from the inhalable particulate network (1979-84).
1995-7

Risk estimates for the most recent mortality data are shown in table 8. Twelve different combinations of PM metrics and lag periods were considered, providing 60 age specific mortality estimates (excluding log mean mortality). Of these, two were significantly negative (which could have occurred by chance) and 10 are significantly positive. The largest PM responses occur for the younger age groups, concurrent mortality and air quality periods, and the restricted data sets. Particle size seems to be less important in this regard. Again, $\mathrm{SO}_{4}{ }^{2-}$ risks seem to depend more on the monitoring locations than on the timing of exposure. Of the 35 age specific $\mathrm{SO}_{2}$ estimates, six are significant, and the optimum timing differs by age group. $\mathrm{NO}_{2}$ is strongly negative for elderly people and strongly positive for the younger groups. Ozone shows a very strong response for ages 65-85, but mainly for concurrent exposures. CO responses are uniformly negative, many of them significantly

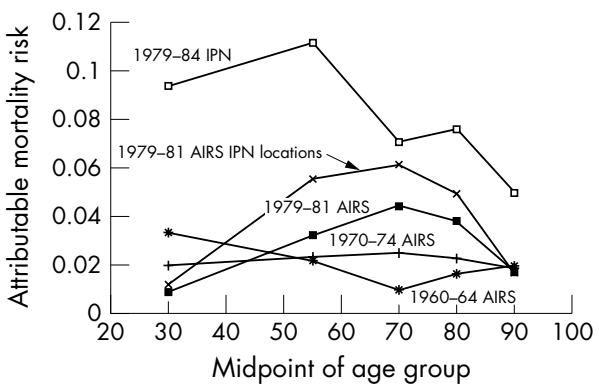

Figure 3 Comparison of attributable risks for 1979-81 mortality from $\mathrm{SO}_{4}^{2}$ according to data source and period of measurement. See table 6 for SEs. 
so. Of the 205 age specific estimates in table 8, 19 are significantly negative and 47 are significantly positive.

Traffic effects were evaluated by regressing residuals against VMTG. The results are very similar to those for the previous period, except that highly significant negative relations are found for ages $\geqslant 75$, even when the data set was restricted to IPN counties. Moreover, the regression coefficients and SEs are similar in both instances.

Age relations are plotted in figure 5. For $\mathrm{SO}_{4}^{2-}$ (fig $5 \mathrm{~A}$ ), a wide range of risks is seen. The earlier AIRS $\mathrm{SO}_{4}{ }^{2-}$ data imply lower risks for elderly people, but these are all very modest risk levels $(<3 \%)$. The IPN $\mathrm{SO}_{4}^{2-}$ data imply the highest risks, but the levels for elderly people are matched by the 1979-81 AIRS data (after correcting for artifact) by restricting the locations to those having IPN data. AIRS $\mathrm{PM}_{2.5}$ shows negligible risks for elderly people, and again, monitoring location seem to control the level of risk for the younger group (fig $5 \mathrm{~B}$ ).

\section{Temporal trends}

The next topic considered is that of temporal trends in risk of mortality by age group and the question of whether there are cohort effects - that is, increased risks shifting to higher ages with the progression of time-that might suggest delayed responses. If only acute effects are present, the largest responses should be for air quality coincident with the mortality period. By contrast, if cumulative effects are present, responses should increase with age and with the passage of time, and such age effects should reflect the generally much worse air quality that was experienced in the United States before about 1970. We used graphic techniques here to try to identify these different types of temporal relations, and we collapsed the five age groups into two, $<65$ and $\geqslant 65$, by averaging results for the appropriate age groups.

No such cohort effects are apparent in figure 6 A-D. For example, in figure $6 \mathrm{~A}$ and $\mathrm{B}$, the younger group tends to have higher risks for all periods, even though the older group would have experienced higher cumulative exposures. Risks associated with $\mathrm{O}_{3}$ and $\mathrm{NO}_{2}$ show increases after 1980; however, the $\mathrm{NO}_{2}$ increase was only for the younger group (fig $6 \mathrm{D}$ ), so that only peak $\mathrm{O}_{3}$ shows a temporal trend that might reflect an effect of cumulative (or repeated) exposures.

Also, we considered the trends in the attributable risks for the log mean mortality (fig $7(\mathrm{~A}-\mathrm{C})$ ), as a measure of the overall associations with air pollution. Responses to most pollutants show decreases since the 1960s; AIRS PM $_{2.5}$ shows an increase in 1995-97, but two periods cannot be used to establish a trend. Responses to peak $\mathrm{O}_{3}$ also suggest a slight increase in 1995-97, but inferring a trend from such small changes is problematic.

\section{Regional patterns}

Spatial autocorrelation can be a concern in cross sectional studies because of the possibility of overstating significance. ${ }^{6234}$ Although a detailed investigation of this issue is beyond the scope of this project, we explored the topic initially by subdividing the nation into six arbitrary regions along lines of latitude and longitude (fig 8). Region 2 was intended to represent the south Florida retirement communities, for example, and Region 1 represents the North east corridor and New England. We computed mean residuals for each region and noted significant differences. Thus, although the residuals from the national models were essentially normally distributed (although the numbers of positive outliers tended to increase with age), they showed regional spatial patterns within those distributions. For ages 45-84, the highest mean residuals were in region 1 (North east) for all periods. For all periods, region 2 (south Florida) had the lowest residuals for ages 65-84 and by far the highest residuals for ages 15-44. Region 6 (midwest) had a general pattern of decreasing mortality residuals over time, for all age groups. Region 4 (South
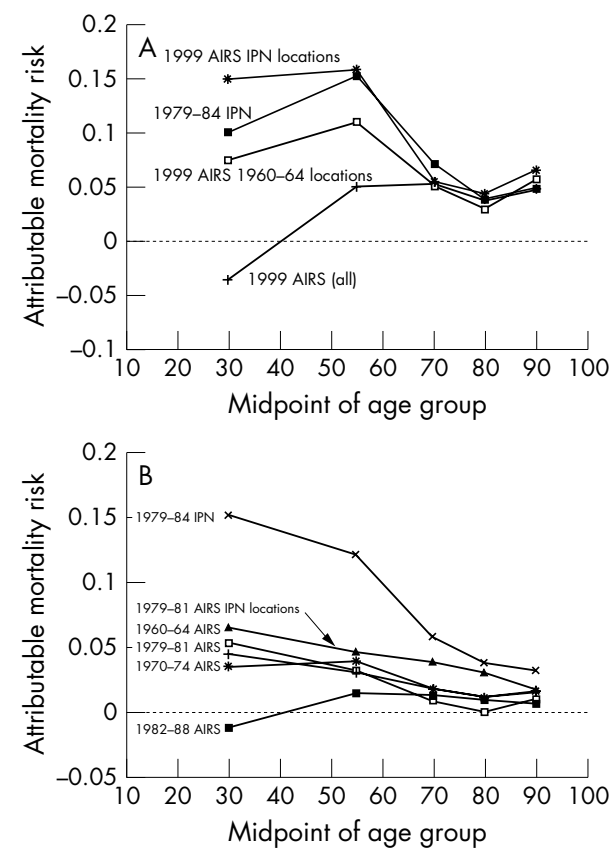

Figure 4 Comparison of attributable risks for 1989-91 as a function of age. (A) for $\mathrm{PM}_{2.5}$ by data source and period of measurement. (B) For $\mathrm{SO}_{4}^{2}$ by data source and period of measurement. See table 7 for SEs.

east) had a general pattern of slightly increasing mortality residuals for elderly people. For ages 65-84, the dispersion in mortality residuals among regions tended to decrease over time, suggesting less spatial heterogeneity across the nation.

We then regressed the national residuals on $\mathrm{PM}_{2.5}$ separately for each region (except region 2, which comprised only 12 counties), for 1989-91 and 1995-97 age specific mortality. For 1989-91, all age groups were significantly associated with $\mathrm{PM}_{2.5}$ in region 6 ( 135 counties with $\mathrm{PM}_{2.5}$ data); by 1995-97, only those aged 64 and under were so associated. Regression coefficients in region 4 (98 counties) were very similar to those in region 6 for both years, but only three of 12 estimates were significant. There were no significant relations with $\mathrm{PM}_{2.5}$ in region 5 ( 85 counties), and in region 3 ( 46 counties), ages $\geqslant 85$ were significantly (positively associated) with $\mathrm{PM}_{2.5}$ in 1989-91 and ages 75-84 were significantly negatively associated in 1995-97. In region 1 (63 counties), $\mathrm{PM}_{25}$ was significantly (positively) associated with ages $15-44$ and $\geqslant 85$ mortality in 1989-91; in 1995-97, ages 15-44 were still positively associated with $\mathrm{PM}_{2.5}$, but there were significant negative relations with ages $65-\geqslant 85$.

Part of these differences may be due to $\mathrm{PM}_{25}$ concentrations, which were higher in regions 4 and 6 in 1999. Thus, the regions with the highest concentrations had the most significant relations, but this does not account for the significant negative relations.

\section{CONCLUDING DISCUSSION Age effects}

Examining mortality-pollution relations by age was a prime objective of the study, and the finding of stronger effects in younger age groups was not expected. The "conventional wisdom" is that air pollution affects primarily the most vulnerable members of a society, for example, the very young and very old. This premise is not supported by most of the results of this study; the risks of those aged 85 and over were often the lowest among age groups (infant mortality was not examined). Perhaps the main advantage of studying mortality patterns stratified by age rather than by cause is the relative certainty of classification. Nevertheless, it may be useful to 

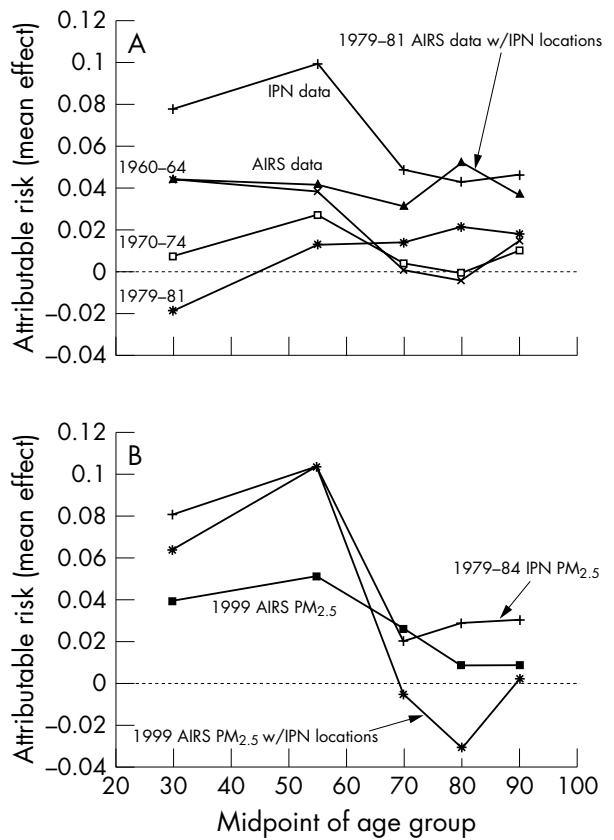

Figure 5 Mean effects (attributable risks) for 1995-97 as a function of age. (A) For $\mathrm{SO}_{4}{ }^{2}$ by data source and period of measurement. (B) For $\mathrm{PM}_{2.5}$ by source, period, and locations of measurement. See table 8 for SEs.

consider the relative patterns of major cause of death with respect to age, during the period of study. The fraction of disease deaths attributed to cancer peaks at about age 60, was about 0.28 in 1973 and about 0.39 in 1991. By contrast, the fraction of deaths attributed to cardiovascular causes rises monotonically after about age 25 , with values for the $\geqslant 85$ age group of about 0.75 in 1973 and 0.59 in 1991. The fraction of deaths attributed to respiratory causes tends to be U shaped, with a minimum of about 0.035 at age 50 in 1973, rising to 0.061 for ages $\geqslant 85$. In 1991, the respiratory fraction was minimal at 0.022 at age 20 , rising to 0.10 for ages $\geqslant 85$. Thus, during the period of study overall death rates have generally decreased, cancer has become relatively more important in middle age, and respiratory disease more important among elderly people, whereas the improvement in longevity has generally come from cardiovascular causes. Only peak ozone shows a pattern of increasing responses for ages $\geqslant 85$, suggesting that $\mathrm{O}_{3}$ may be a candidate predictor for respiratory mortality, although the increasing trend for respiratory deaths among elderly people is perhaps more likely to be due to delayed effects of smoking.

Considering the original question posed, that of distinguishing the sum of acute responses from truly chronic effects, we note that the magnitudes of the responses for elderly people are often comparable with those found in time series (acute) studies ${ }^{35}$ and lower than those reported in some prospective cohort studies. ${ }^{3}$ If genuine long term effects exist, the risks should increase with cumulative exposure-that is, with age. This is only found for peak $\mathrm{O}_{3}$ in our results. Furthermore, there is typically less coherence among the estimated risks for younger age groups $(<65)$, suggesting that further model development may be in order, for example to investigate uncontrolled confounding.

\section{Comparisons with previous studies}

Before 1993, long term associations between air pollution and mortality had only been estimated by means of ecological studies. Such an age specific study for about 100 United States cities found the strongest effects among elderly people in 1969-71, with attributable risks from about $4 \%$ to $11 \%$, based mainly on $\mathrm{SO}_{4}^{2-}$ and TSP. ${ }^{31}$ The present study found substantially lower risks for this period (table 5), which may be due to the more comprehensive models used. The present study also found lower risks than a previous study of 1980 mortality in United States cities ${ }^{32}$ (log mean mortality compared with all age mortality), although the two studies agree in finding similar results for $\mathrm{SO}_{2}, \mathrm{NO}_{x^{\prime}}$ and $\mathrm{SO}_{4}^{2-}$ and negative results for CO.

It is also of interest to compare these findings with those of more recent prospective cohort studies (after converting their relative risk estimates to attributable risks based on mean concentrations). ${ }^{33}$ Pope et al ${ }^{4}$ used the IPN PM 2.5 data for the largely middle class American Cancer Society cohort, aggregated to the metropolitan area (MSA) level. Their attributable
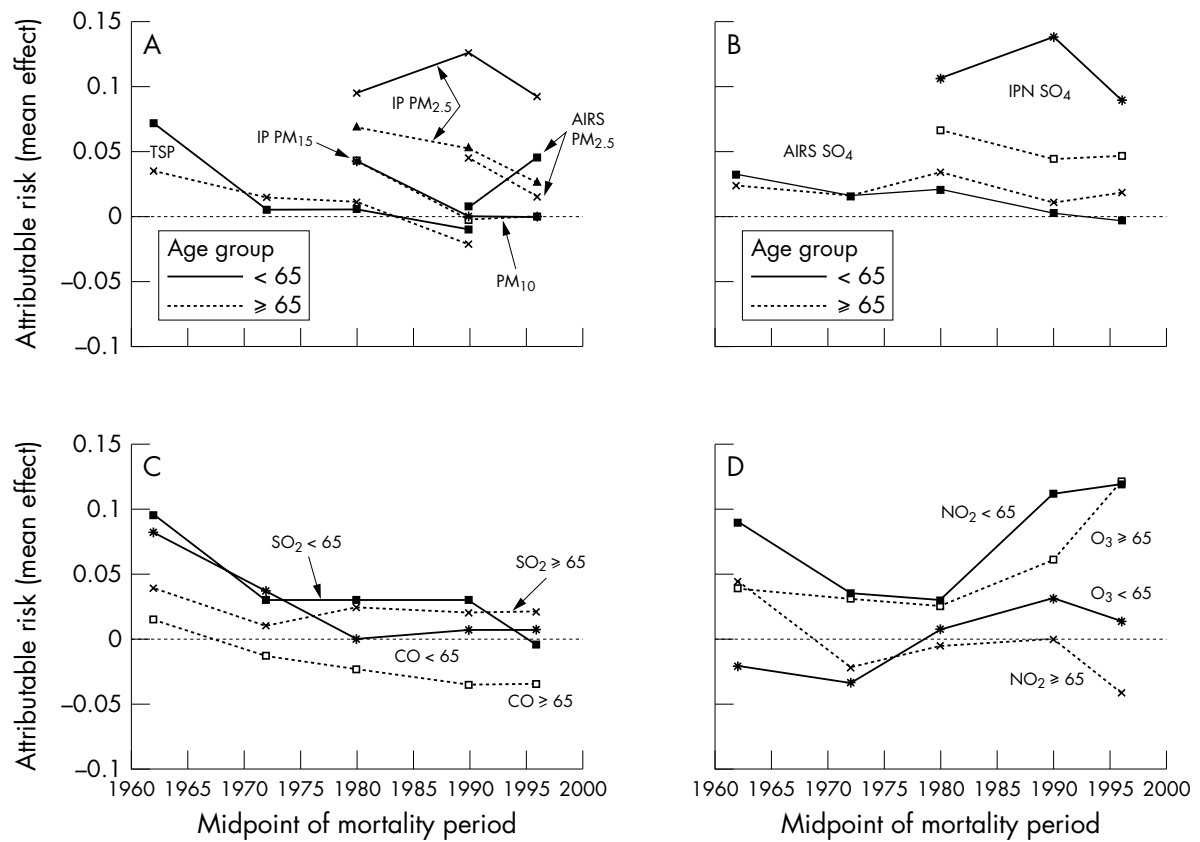

Figure 6 Trends in attributable risks of mortality by aggregated age group (A) for various $\mathrm{PM}$ measures, (B) for $\mathrm{SO}_{4}{ }^{2},(\mathrm{C})$ for $\mathrm{SO}_{2}$ and 95 th percentile $\mathrm{CO}$, and (D) for $\mathrm{NO}_{2}$ and 95th percentile $\mathrm{O}_{3}$ (see tables 4-8 for applicable SEs). 

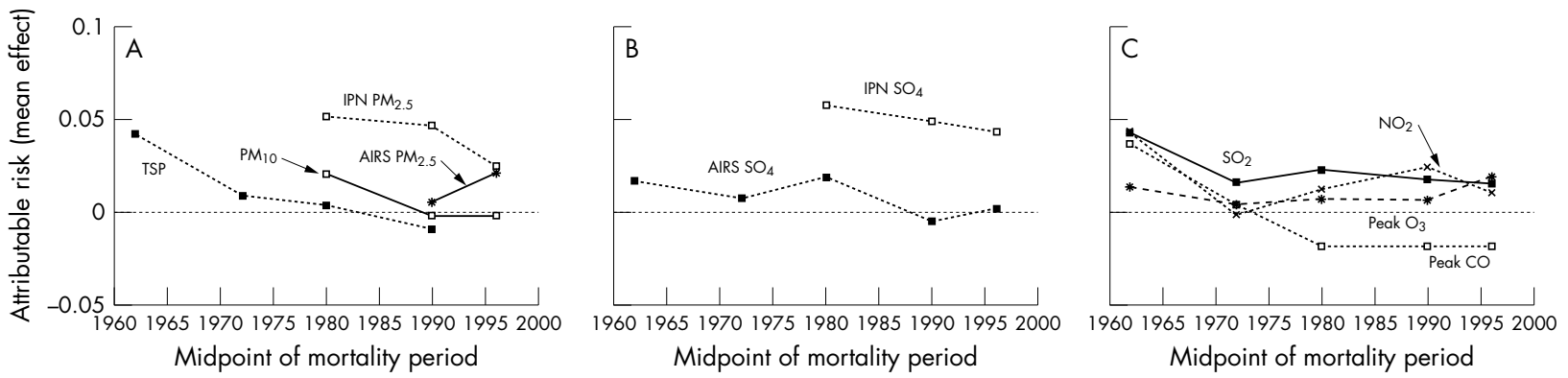

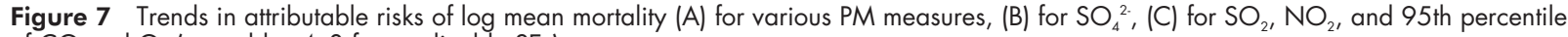
of $\mathrm{CO}$ and $\mathrm{O}_{3}$ (see tables 4-8 for applicable SEs).

risk for the 1982-89 period was about 0.12; our comparable estimates for 1979-81 for the whole country range from 0.06 to 0.10 , depending on age. For 1989-91, our estimates ranged from 0.04 to 0.15 . For AIRS $\mathrm{SO}_{4}{ }^{2-}$ in 151 MSAs, Pope et al found an attributable risk of 0.077 ; our estimates ranged from 0.03 to 0.10 , again depending on age and without adjustment for filter artifact. We consider that these comparisons show reasonable agreement with Pope et al for that period, but it should also be noted that our results indicate that the age distribution of the cohort may be very important.

The largest estimates of long term risk of mortality are from the Harvard six cities study, ${ }^{3}$ corresponding to attributable risks of $0.22-0.25$. We had IPN data for four of the six locations (Boston, Steubenville, St Louis, and Topeka). We used a nearby location in Wisconsin and two other cities in Tennessee as stand ins for Portage and Harriman, and plotted the elderly mortality residual versus IPN PM $_{2.5}$ for these locations in figure 9. These points form a reasonably linear relation, with a net span in risk of 0.22 , in excellent agreement with the prospective cohort study results. ${ }^{3}$

Points of agreement with the most recent prospective cohort study ${ }^{5}$ include the findings of lower risks in more recent periods, significant risks attributed to peak $\mathrm{O}_{3}$ (at about 0.04 to 0.14 ), negative responses to $\mathrm{CO}$, and negligible risks of TSP/PM $\mathrm{PM}_{10}$. However, that prospective cohort study also found apparent beneficial effects of $\mathrm{PM}_{2.5}$ and $\mathrm{SO}_{4}^{2-}$, whereas the present study does not.

The results for CO may warrant additional discussion. Significantly positive associations are found with younger mortality, especially in the early years, but there are also significant negative findings for elderly people in more recent periods. Significant negative relations have also been reported previously in both cohort ${ }^{56}$ and ecological ${ }^{32}$ studies of air pollution and mortality. These apparently anomalous findings have mainly been ignored, but in view of recent toxicological support for low concentrations of CO, albeit in studies of com-

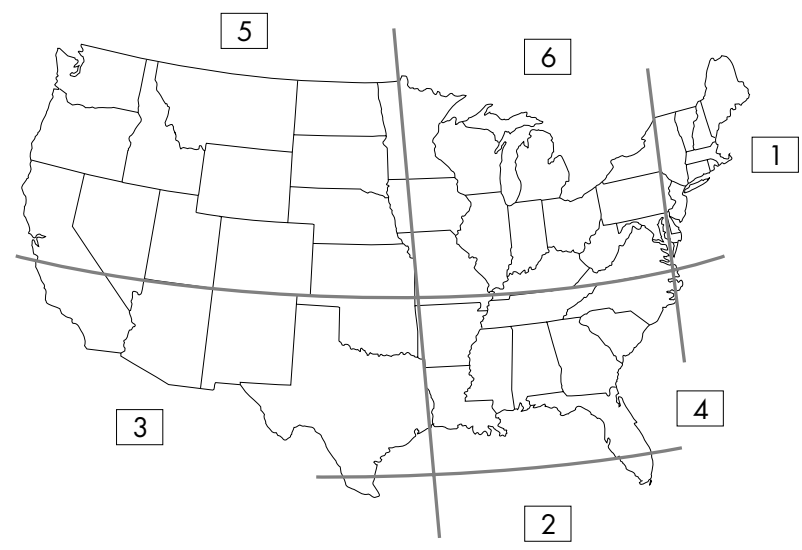

Figure 8 Regions of the United States. promised animals, ${ }^{36}$ the interpretation of these consistent negative epidemiological findings should be reconsidered.

\section{Summary of findings and suggestions for future cohort studies}

In interpreting the results of these analyses, caution is required because one can never be sure that all the important confounders have been controlled, that the regression models used are indeed appropriate, or that the two stage estimation procedure has not introduced some error. Of course, such cautions are also appropriate for prospective cohort studies, for which some sensitivities have recently been found. ${ }^{56}$ Nevertheless, certain aspects of the present study are compelling, such that the findings should be considered in the design and interpretation of future prospective cohort studies. These aspects include:

(1) The study covers the entire nation over a period of about 40 years and includes all criteria pollutants except lead.

(2) The study includes a wider range of (non-pollutant) predictor variables than has been considered in previous studies and finds the expected directions of those effects.

(3) The study conforms to the usual requirements for a valid regression (significance of the predictors, absence of excessive collinearity, normal distributions of residuals). Possible spatial autocorrelation of residuals bears further investigation.

(4) Dose-response plots suggest pollutant thresholds in the early period that are in reasonable agreement with national ambient air quality standards.

(5)The regression results agree with various previous long term studies of air pollution and mortality, including prospective cohort studies, for those specific situations.

(6)Those previous results do not seem to be applicable to the entire United States nor to future years.

The findings of this study that should be confirmed with data at an individual level include:

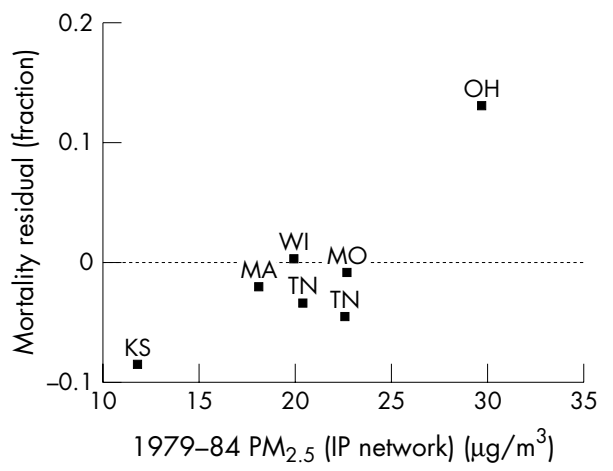

Figure 9 Mortality: $\mathrm{PM}_{2.5}$ relation simulating the Harvard six cities. KS, Topeka; MA, Boston; TN, Nashville and Chattanooga; WI, Rock County; MO, St Louis; $\mathrm{OH}$, Steubenville. Mortality data are average residuals for ages $\geqslant 65$. 


\section{Main messages}

- The long term associations between premature mortality and ambient air quality vary substantially by age group and pollutant, as well as according to the locations and periods considered. Significant associations are found for all pollutants, but the associations with peak $\mathrm{CO}$ tend to be negative after 1980

- Although cumulative exposure to air pollution increase with age, long term mortality risks seem to be higher in the younger age groups (except for peak ozone in recent years). Thus, there is little evidence for cumulative effects.

- There is little coherence between these long term relations and the results of time series analyses of acute risks, in that the significant pollutants and age groups differ.

- Based on log mean mortalities for ages 15 and over, most of the attributable risks are less than $5 \%$.

- Response thresholds are apparent in the early periods, after which the long term risks attributed to most pollutants decrease.

- Increasing the number of locations considered in the analysis usually decrease the apparent attributable risks.

- A significant slope does not always imply a plausible (monotonic) dose-response relation.

\section{Policy implications}

- Long term relations between mortality and air quality in the United States have changed significantly over time; thus results from studies of past decades cannot be assumed to pertain to the present or to the future.

- Reduction of the high air pollution levels of the 1960s seems to have improved longevity in the United States; comparable benefits from further reductions may be problematic.

- The characteristics of these relations are generally consistent with the results of previous cohort and ecological studies, but they are not consistent with expectations for either acute or chronic responses.

(1) Mortality responses to air pollution have been decreasing over time for some pollutants and seem to have increased for others.

(2) Apparent thresholds were found in dose-response characteristics that may account for these decreases.

(3) The role, if any, of cumulative exposure is unclear (indications were only found in responses to peak ozone among elderly people).

(4) The results seem to be sensitive to the monitoring locations included. It seems that, as a rule of thumb, the fewer locations comprising a significant relation, the steeper the slope of the dose-response function. Future studies should thus strive to be more inclusive and hence be more representative.

(5) The existence of both positively and negatively significant mortality relations with various pollutants must be rationalised.

(6) Apparent differences in response by age must be recognised in cohort studies, perhaps by including age interaction terms for various predictor variables, including air quality.

Finally, we think that this paper shows how an ecological analysis can be a useful accompaniment to the extant suite of prospective cohort studies. Our findings must be regarded as preliminary, pending the consideration of alternative regression models and techniques, additional dietary variables, spatial autocorrelation, and multipollutant models. It will also be of interest to include more recent air quality and mortality data, to determine if the temporal trends shown in this paper have continued. It would now also seem to be appropriate to investigate the sources of heterogeneity among the results of the various extant cross sectional studies of ambient air quality and mortality.

\section{ACKNOWLEDGEMENTS}

The original database used in this work was developed with support from the American Petroleum Institute; however, that database is now the intellectual property of the authors. Support for the analyses presented in this paper was provided by the Alliance of Automobile Manufacturers. We also thank three anonymous reviewers for their helpful comments.

\section{APPENDIX: CORRELATIONS AMONG AIR QUALITY VARIABLES \\ Correlations among pollutants for different periods}

Table 9 presents spatial correlations by period between pollutants. Because the locations for which data were available varied by pollutant and year, pairwise correlations are shown, based on the largest possible number of pairs in each case. Note that the PM metric used varies with the period and that additional detail is provided for size classified PM for 1995-97. Of the 80 correlations shown, the highest value is 0.83 and only five values exceed 0.5 . Two of these were for $\mathrm{SO}_{4}{ }^{2}$ versus $\mathrm{SO}_{2}$; this relation may be influenced by artifact $\mathrm{SO}_{4}{ }_{4}^{2-}$ formed on the sampling filter from $\mathrm{SO}_{2}$ in the air passing through.

Table 9 also includes row averages and coefficients of variation $(\mathrm{CV}$, $\mathrm{SD} /$ mean) that were intended to characterise the consistency of relations between pollutants across the entire period. The most consistent relations over time are those of $\mathrm{SO}_{2}$ versus $\mathrm{NO}_{2}, \mathrm{NO}_{2}$ versus $\mathrm{CO}$, and $\mathrm{SO}_{4}{ }^{2 \cdot}$ versus peak $\mathrm{O}_{3}$, but none of them seem to be high enough to create serious collinearity problems. The bottom five rows of the table comprise the averages across pollutant combinations; in other words, the entry of 0.54 for $\mathrm{SO}_{4}^{2-}$ in 1960-64 is the average of all five pollutant pairs that include $\mathrm{SO}_{4}{ }^{2}$. On this basis it seems that pollutants were more intercorrelated in the earliest period, for which there were fewest observations, mainly confined to large cities.

Correlations between VMTG and air quality were considered separately and were generally modest, depending somewhat on the numbers of counties considered. The ranges were: VMTG versus $\mathrm{PM}_{25}, 0.1-$ $0.2 ; \mathrm{PM}_{10}, 0.08-0.18 ; \mathrm{CO}, 0.13-0.26 ; \mathrm{NO}_{2}, 0.55-0.64 ; \mathrm{SO}_{4}^{2-}, 0.18-0.21$; $\mathrm{SO}_{2}, 0.28-0.43$; peak $\mathrm{O}_{3}, 0.09-0.12$; average $\mathrm{O}_{3},-0.15$ to -0.08 . Thus, $\mathrm{NO}_{2}$ seems to be the best air quality proxy for traffic density and the relatively strong correlations with $\mathrm{SO}_{2}$ suggest that VMTG is also related to the cities of the north east with high population density. The low correlations between VMTG and $\mathrm{O}_{3}$ probably reflect downwind transport of peak $\mathrm{O}_{3}$ values into lower density suburban counties. Air quality variables for 1989-91 and 1995-97 relate better to VMTG than those from 1979-81.

\section{Correlations between periods}

We also considered correlations among periods for each pollutant (fig 10). These correlations tended to decrease with increasing time between periods (up to 30 years), but they are generally higher than the correlations between pollutants. This means that it will be easier to distinguish responses to one pollutant from those of another than to identify the appropriate periods with certainty. As many pollutants and periods are involved, we characterised these relations by the time

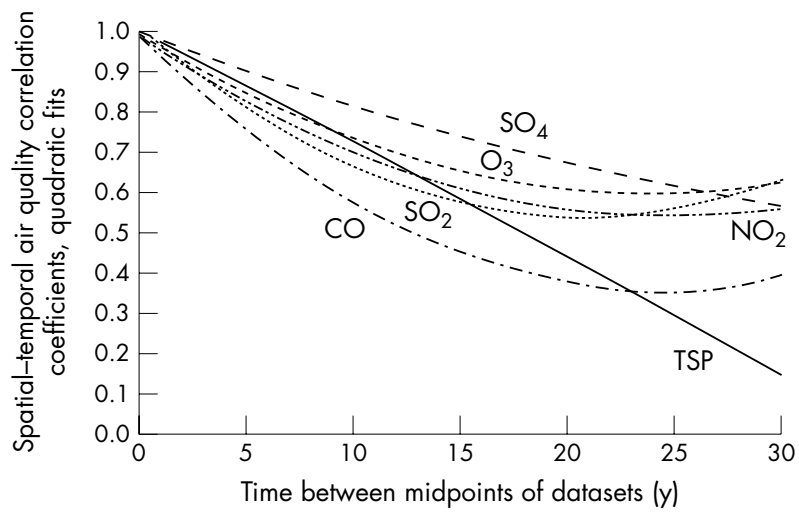

Figure 10 Quadratic fits to the relations between spatial air quality correlations for six different pollutants and the mean time between measurement periods. 
Table 9 Spatial correlations among pollutants (pairwise)

\begin{tabular}{|c|c|c|c|c|c|c|c|c|c|}
\hline & $\begin{array}{l}\text { 1960-64 } \\
\text { (TSP) }\end{array}$ & $\begin{array}{l}\text { 1970-74 } \\
\text { (TSP) }\end{array}$ & $\begin{array}{l}\text { 1979-81 } \\
\text { (TSP) }\end{array}$ & $\begin{array}{l}\text { 1989-91 } \\
\text { (TSP) }\end{array}$ & $\begin{array}{l}1995-97 \\
\left(\mathrm{PM}_{10}\right)\end{array}$ & $\begin{array}{l}\text { 1995-97 } \\
\text { (CP) }\end{array}$ & $\begin{array}{l}1995-97 \\
\left(\mathrm{PM}_{2.5}\right)\end{array}$ & Mean & $\mathrm{CV}$ \\
\hline PM CO & 0.47 & -0.02 & 0.13 & 0.32 & 0.30 & 0.30 & -0.13 & 0.24 & 0.70 \\
\hline $\mathrm{PMNO}_{2}$ & 0.23 & 0.13 & 0.48 & 0.46 & 0.34 & 0.23 & 0.25 & 0.33 & 0.41 \\
\hline $\mathrm{PM} \mathrm{SO}_{4}^{2-}$ & 0.57 & 0.03 & 0.03 & -0.02 & 0.23 & -0.27 & 0.55 & 0.17 & 1.30 \\
\hline $\mathrm{PM} \mathrm{SO}_{2}$ & 0.27 & 0.14 & 0.28 & 0.08 & 0.14 & -0.01 & 0.23 & 0.18 & 0.43 \\
\hline $\mathrm{PMO}_{3}$ & & 0.19 & 0.12 & 0.24 & 0.32 & -0.01 & 0.53 & 0.22 & 0.34 \\
\hline $\mathrm{SO}_{4}^{2-} \mathrm{O}_{3}$ & & 0.38 & 0.31 & 0.43 & 0.50 & & & 0.41 & 0.17 \\
\hline $\mathrm{SO}_{4}^{2-} \mathrm{CO}$ & 0.34 & 0.05 & -0.14 & -0.32 & -0.36 & & & -0.09 & -3.00 \\
\hline $\mathrm{SO}_{4}{ }^{2-} \mathrm{NO}_{2}$ & 0.41 & 0.37 & 0.15 & 0.30 & 0.23 & & & 0.29 & 0.32 \\
\hline $\mathrm{SO}_{4}^{2-} \mathrm{SO}_{2}$ & 0.83 & 0.23 & 0.46 & 0.56 & 0.38 & & & 0.49 & 0.41 \\
\hline $\mathrm{SO}_{2} \mathrm{CO}$ & 0.27 & 0.28 & 0.18 & 0.07 & 0.01 & & & 0.16 & 0.66 \\
\hline $\mathrm{SO}_{2} \mathrm{NO}_{2}$ & 0.39 & 0.51 & 0.48 & 0.43 & 0.48 & & & 0.46 & 0.09 \\
\hline $\mathrm{SO}_{2} \mathrm{O}_{3}$ & & 0.06 & 0.17 & 0.19 & 0.34 & & & 0.19 & 0.52 \\
\hline $\mathrm{NO}_{2} \mathrm{CO}$ & 0.36 & 0.48 & 0.43 & 0.41 & 0.48 & & & 0.43 & 0.10 \\
\hline $\mathrm{NO}_{2} \mathrm{O}_{3}$ & & 0.15 & 0.47 & 0.43 & 0.29 & & & 0.34 & 0.38 \\
\hline $\mathrm{COO}_{3}$ & & -0.06 & 0.01 & 0.13 & 0.16 & & & 0.06 & 1.49 \\
\hline PM average & 0.39 & 0.07 & 0.23 & 0.21 & 0.25 & 0.06 & 0.23 & 0.23 & \\
\hline $\mathrm{CO}$ average & 0.36 & 0.15 & 0.12 & 0.12 & 0.12 & & & 0.16 & \\
\hline $\mathrm{SO}_{4}{ }^{2-}$ average & 0.54 & 0.21 & 0.16 & 0.19 & 0.20 & & & 0.25 & \\
\hline $\mathrm{SO}_{2}$ average & 0.44 & 0.24 & 0.31 & 0.27 & 0.27 & & & 0.30 & \\
\hline $\mathrm{O}_{3}$ average & & 0.14 & 0.22 & 0.28 & 0.32 & & & 0.24 & \\
\hline $\mathrm{NO}_{2}$ average & 0.28 & 0.33 & 0.40 & 0.41 & 0.36 & & & 0.36 & \\
\hline
\end{tabular}

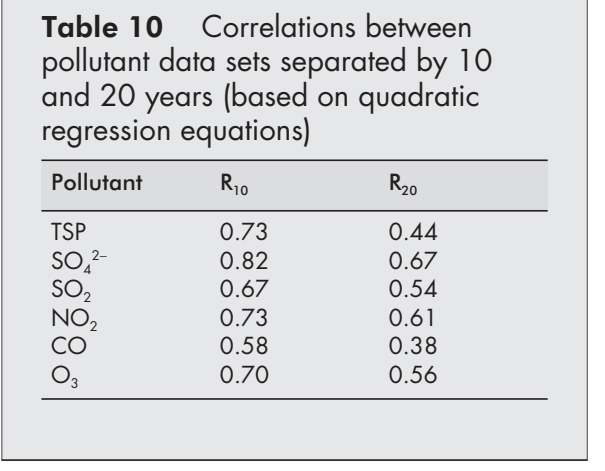

difference between periods. This paradigm assumes that the relation between pollutants measured in 1960-64 and 1970-74 would be the same as that between those measured in 1979-81 and 1989-91, for example. Figure 10 shows the quadratic fits to the pairwise correlations for each of the six major pollutants considered. TSP and (to a slightly lesser extent) $\mathrm{SO}_{4}^{2 \cdot}$ correlations decreased essentially linearly over time, whereas the correlations between gaseous pollutants became minimal after about 20 years of difference between periods.

The quadratic regression equations were used to compare predicted correlations for pollutant data sets separated by 10 and 20 years (table $10)$.

These calculations (and fig 10 ) indicate that spatial patterns of $\mathrm{SO}_{4}^{2 \cdot}$ have had the least variability over time, whereas spatial patterns in $\mathrm{CO}$ have been the most variable. The patterns for TSP, $\mathrm{SO}_{2}, \mathrm{NO}_{2}$, and $\mathrm{O}_{3}$ have about the same (intermediate) degree of temporal variability at 10 years of separation, but at 20 years, most of the correlations are less than 0.6.

For comparison, the correlation between $\mathrm{PM}_{25}$ in 1979-84 from the IP network and $\mathrm{PM}_{2.5}$ in 1999 from the new AIRS network is 0.71, which is higher than the corresponding TSP value and slightly lower than the correlation for $\mathrm{SO}_{4}^{2-}$ (for 18 years). However, the correlation between $\mathrm{PM}_{2.5}$ from the IP network and $\mathrm{PM}_{10}$ in 1999 was 0.48 , which corresponds very well with the TSP relation for 18 years in figure 10 . Note also that the correlation between $\mathrm{SO}_{4}^{2 \cdot}$ measured in the IP network (1979-84) and $\mathrm{SO}_{4}^{2 \cdot}$ measured by AIRS in 1979-81 is only 0.75 , which reflects uncertainties associated with the types of filters used.

\section{Authors' affiliations}

F W Lipfert, S C Morris, Environmental Consultants, 23 Carll Court, Northport, New York, USA

\section{REFERENCES}

1 US Environmental Protection Agency. The benefits and costs of the Clean Air Act, 1970 to 1990, report prepared for the United States Congress. Washington, DC: USEPA, 1996:392.

2 Abbey DE, Nishino N, McDonnell WF, et al. Long-term inhalable particles and other air pollutants related to mortality in non-smokers. Am J Respir Crit Care Med 1999;159:373-82.

3 Dockery DW, Pope CA III, Xu X, et al. An association between air pollution and mortality in six US cities. N Engl J Med 1993;329:17539.

4 Pope CA III, Thun M, Namboodiri MM, et al. Particulate air pollution as a predictor of mortality in a prospective study of US adults. Am J Respir Crit Care Med 1995;151:669-74

5 Lipfert FW, Perry HM Jr, Miller JP, et al. The Washington University-EPRI veterans' cohort mortality study: preliminary results. Inhal Toxicol 2000;12(suppl 4):41-73.

6 Krewski D, Burnett RT, Goldberg MS, et al. Reanalysis of the Harvard six cities study and the American Cancer Society study of particulate air pollution and mortality, special report. Cambridge, MA: Health Effects Institute, 2000.

7 Kunzli N, Tager IB. The semi-individual study in air pollution epidemiology: a valid design as compared to ecological studies, Environ Health Perspect 1997;105:1078-83.

8 Blakely TA, Woodward AJ. Ecological effects in multi-level studies, J Epidemiol Community Health 2000;54:367-74.

9 Pearce N. The ecological fallacy strikes back. J Epidemiol Community Health 2000:54:326-7.

10 Schwartz S, Carpenter KM. The right answer for the wrong question: Consequences of type III error for public health research. Am J Public Health 1999;89:1 175-80.

11 Lipfert, FW. The use and misuse of surrogate variables in environmental epidemiology. J Environ Med 1999:1:267-78.

12 Robinson WS. Ecological correlations and the behavior of individuals. Am Soc Rev 1950;15:351-7.

13 Morgenstern H. Uses of ecologic analysis in epidemiologic research. Am J Public Health 1982;72:1336-44.

14 Greenberg M, Burrington M, Smith C. Guidelines and an illustration of the use of ecological data for seeking clues of excess risk. Socioeconomic Planning Sciences 1984;18:293-9.

15 Lipfert FW, Morris SC III. Cross-sectional analyses of long-term relationships between air pollution and mortality in the United States. Final report, task 1, development of national data bases, report to the American Petroleum Institute, May 1999. Avaible from author on request.

16 Lipfert, FW, Morris, SC III. Temporal and spatial trends in age-specific mortality rates, US Counties, 1960-97. Report to the Alliance of Automobile Manufacturers. September 2000. Available from author on request

17 Schoen $\mathbf{R}$. The geometric mean of the age-specific death rates as a summary index of mortality. Demography 1970;7:317-24.

18 Apte MG, Nero AV, Rezvan KL. Meteorological database for the United States. Indoor Air 1998:8:61-7.

19 Baldwin JL. Climates of the United States. Washington, DC: National Oceanic and Atmospheric Administration, US Government Printing Office, 1973.

20 Leis HP Jr. The relationship of diet to cancer, cardiovascular disease, and longevity. Int Surg 1991;76:1-5.

21 Weiss MJ. Latitudes and attitudes, an atlas of American Tastes, trends, politics, and passions. Boston, MA: Little, Brown, 1994:204-23. 
22 Abbey DE, Ostro BE, Petersen F. Estimating fine particulates less than $2.5 \mu \mathrm{m}$ in aerodynamic diameter $\left(\mathrm{PM}_{2.5}\right)$ from airport visibility data in California. J Expo Anal Environ Epidemiol 1995;5:161-80.

23 Lipfert FW. Filter artifacts associated with particulate measurements: recent evidence and effects on statistical relationships. Atmosphere and Environment 1994:28:3233-49.

24 Krewski D, Wigle D, Clayson DB. Role of epidemiology in health risk assessment. Recent Results Cancer Res 1990;1 20:1-24.

25 Rose G. Incubation period of coronary heart disease. BM 1982;284:1600-1.

26 Rothman KJ. Induction and latent periods. Am J Epidemio 1981;114:253-9.

27 Zidek JV, Wong H, Le ND. Casuality, mearsurement error, and multicollinearity in epidemiology. Environmetrics 1996:7:441-51.

28 Barker DJP. Mothers, babies, and health in later life. London: Churchill Livingston, 1998

29 Shaheen S. The beginnings of chronic airflow obstruction. Br Med Bull 1997;53:58-70

30 Young FW. An explanation of the persistent doctor-mortality association. J Epiderniol Community Health 2001;55:80-4.
31 Lipfert FW. Statistical studies of mortality and air pollution: multiple regression analysis stratified by age group. Sci Total Environ 1980;16:103-22.

32 Lipfert FW, Malone RG, Daum ML, et al. A statistical study of the macroepidemiology of air pollution and total mortality. Report 52122 Upton, NY 11973: Brookhaven National Laboratory, April 1988.

33 Lipfert FW, Estimating air pollution-mortality risks from cross-sectional studies: prospective $v$ ecologic study designs. In: particulate matter, health, and regulatory issues. VIP 49. Proceedings of the International Specialty Conference. Pittsburgh, PA: AWMA Publishers 1995:78-102.

34 Burnett R, Ma R, Jerrett $M$, et al. The spatial association between community air pollution and mortality: a new method of analyzing correlated geographic cohort data. Environ Health Perspect 2001;109(suppl 3):375-80.

35 Lipfert FW, Wyzga RE. Air pollution and mortality: issues and uncertainties, J Air Waste Manag Assoc 1995;45:949-66.

36 Fujita T, Toda K, Karimova A, et al. Paradoxical rescue from ischemic lung injury by inhaled carbon monoxide driven by derepression of fibrinolysis. Nat Med 2001;7:598-604

Answers to multiple choice questions on Translating evidence about occupational conditions into strategies for prevention by DK Verma, JT Purdham, and

HA Roels, on pages 205-214

(1) (a) false; (b) false; (c) false; (d) true; (e) true

(2) (a) true; (b) false; (c) false; (d) true; (e) false

(3) (a) true; (b) false; (c) true; (d) true; (e) false

(4) (a) false; (b) true; (c) false; (d) false; (e) true

(5) (a) true; (b) false; (c) true; (d) false; (e) true 